\title{
OPPRESSED BUT NOT BETRAYED: A COMPARATIVE ASSESSMENT OF CANADIAN REMEDIES FOR MINORITY SHAREHOLDERS AND OTHER CORPORATE CONSTITUENTS
}

\author{
DeBorah A. DeMotT*
}

INTRODUCTION

After visiting Canada for any length of time, even well-traveled U.S. citizens may be surprised by the differences between the United States and its northern neighbor. Intimate geographical proximity and extensive trade ties lead to expectations of great similarity that, upon closer inspection, appear unfounded. ${ }^{1}$ Despite the noticeable influence of U.S. statutory and case law, Canadian corporate law and securities regulation differ in significant respects from their counterparts south of the border. ${ }^{2}$ Even more striking, perhaps, are differences

Copyright ( 1993 by Law and Contemporary Problems
$*$ Professor of Law, Duke University.
I am grateful to Philip Anisman, Frederick Lambert, and Jeffrey Macintosh for their comments on earlier drafts of this article.

1. Federalism has had visibly different consequences in the two countries. Canadian federalism appears not to encompass the degree of national economic unity mandated by norms of federalism developed in the United States. The Canadian legislation that is the functional equivalent of the Uniform Commercial Code is not uniform among the provinces. Moreover, Canadian federal law indulges interprovincial barriers to trade that may surprise U.S. visitors. "Canadian" brands that are well known in the United States-Moosehead beer is a leading example-are not available for sale in all Canadian provinces as a result of various interprovincial barriers. Beer produced in New Brunswick (like Moosehead) is excluded from sale in Ontario. It may be, of course, that Moosehead was designed by Canadians especially to market in the United States, designed on the basis of Canadian perceptions of what would sell as a "Canadian" product south of the border. If so, the relative strength of north-south trade ties, soon perhaps to be nurtured through the North American Free Trade Agreement, contrasted with the weakness of east-west ties, is striking.

Like the United States, Canada has federal courts of limited subject matter jurisdiction, separate from its provincial courts of general jurisdiction. Canadian norms of federalism, however, defeated the development of a doctrine of ancillary jurisdiction for federal courts; in Canada, unlike the United States, ancillary jurisdiction encompasses only matters governed by federal law over which the court could have had independent original jurisdiction. See Peter W. Hogg, Federalism and the Jurisdiction of Canadian Courts, 30 U.N.B. L.J. 9 (1981). The result is that issues and claims that arise in factually related disputes are centrifugally dispersed into separate actions in different courts.

2. Contemporary Canadian corporation statutes, traceable to the new Ontario Business Corporations Act adopted in 1970, draw heavily on U.S. statutory patterns. See JACOB S. ZIEGEL ET AL., CASES AND MATERIals ON PARTNERShiPS AND CANADIAN BUSINESS CORPORATIONS 99 (2d ed. 1989). Canadian institutions reflect different allocations of legislative and regulatory authority. Unlike the United States, Canada has a federal corporations statute-the Canada Business Corporations Act ("CBCA") -as well as provincial corporation statutes. Whether to incorporate under the CBCA or a provincial statute is an election made by the incorporators. See id. at 233. Professor Daniels reports less 
in patterns of share ownership, and thus of corporate control, in the two countries. Canada is noteworthy for its highly concentrated share ownership and for the predominant position of a small number of family-based groups as share owners. ${ }^{3}$ Of the 300 large, publicly traded companies included in the Toronto Stock Exchange ("TSE") index, $60.3 \%$ have a shareholder or coalition of associated shareholders with legal control, while only fourteen percent of TSE companies are widely held. ${ }^{4}$ Comparable statistics for the United States are almost precisely obverse. ${ }^{5}$ Thus, a substantially larger number of Canadian companies with public equity investors also have controlling shareholders and, as a result, more occasions for intershareholder conflict.

This article will examine the distinctive Canadian contribution to the resolution of conflict among shareholders, and of conflict between nonshareholder constituents (such as creditors) and persons controlling a corporation, typically its shareholders and directors. Part II discusses the aspects of corporate law that define the duties that a corporation's majority shareholder owes to its minority shareholders. Part III then examines the vehicles of litigation available to minority shareholders to contest acts done by or at the behest of majority shareholders, as well as the more prominent role Canadian securities regulation plays in controlling acts of majority shareholders. Part IV evaluates claims of unfair treatment by corporate constituents, other than minority shareholders, and the resolution of such claims in Canada and the United States. To sharpen its comparisons, the article periodically sets forth leading cases from each jurisdiction and explores their likely resolution in the other country.

inter-provincial competition for incorporation business than typifies jurisdictions in the United States. See Ronald J. Daniels, Should Provinces Compete? The Case for a Competitive Corporate Law Market, 36 MCGILL L.J. 130, 179-88 (1991). The other principal difference is that in Canada, securities regulation is currently a provincial matter. Unquestionably, the most significant of the provincial bodies is the Ontario Securities Commission ("OSC"); the OSC's importance is largely a result of the prominence of the Toronto Stock Exchange among Canadian exchanges. The OSC's contribution to the questions analyzed in this article is discussed infra at text accompanying notes 167-75.

3. Family dynasties continue to play a visible role in shaping and controlling the destinies of Canadian corporations. See, e.g., Deborah A. DeMott, Comparative Dimensions of Takeover Regulation, 65 WASH. U. L.Q. 69, 74 (1987) ( ${ }^{\text {"In } 1985, \ldots . . ~ n i n e ~ f a m i l i e s ~ w e r e ~ r e p o r t e d ~ t o ~ c o n t r o l ~} 46 \%$ of the top 300 companies traded on the Toronto Stock Exchange."). Cross-ownership among dynasties is not unusual. The fortunes of the Edper Group (controlled by the Bronfman family) are linked to the fate of Olympia \& York Developments, Ltd. (controlled by the Reichmann family) through their joint ownership of Trizec Corp., a New York-based real estate developer with substantial Canadian holdings. See Clyde H. Farnsworth, The Bronfmans' Leveraged Leviathan, N.Y. TIMES, May 24, 1992, \& 3, at 1, 6. Securities in Edper-related companies comprise more than $5 \%$ of the Toronto Stock Exchange. See Suzanne McGee, Bronfman's Giant Edper Empire Circles the Wagons, WALL ST. J., Dec. 2, 1992, at B4. Rumors about Edper's stability - their gravity enhanced by Olympia and York's insolvency-led not only to record-low prices for Edper-related securities in late 1992 but helped drive down the value of the Canadian dollar.

4. See Ronald J. Daniels \& Jeffrey G. MacIntosh, Toward a Distinctive Canadian Law Regime, 29 OSGOODE HALL L.J. 863, 884 (1992).

5. See id. Among the 1990 Fortune 500 companies, $12 \%$ had a shareholder or group of shareholders with effective control, while $63 \%$ were widely held. Id. Of the Fortune 500 companies, $6.6 \%$ had unclassified ownership structures. Id. at 884 n.41. 
Readers in the United States may initially be startled by two basic aspects of Canadian law. First, recent Canadian case law holds that a majority shareholder is not a fiduciary toward the minority, while Canadian statutes expressly protect the interests of a large cast of nonshareholder constituents, who may enforce their rights through private litigation. Second, several Canadian corporation statutes contain provisions enabling shareholders and various nonshareholder constituents to challenge actions of corporations or their directors on the basis that the action oppresses, unfairly disregards, or is unfairly prejudicial toward holders of interests protected by the statute. ${ }^{6}$

II

\section{LEgal CONSTRAINTS ON CONTROLLING SHAREHOLdERS IN CANADA}

\section{A. General Alternatives to Majoritarianism}

It is well settled in the United States that a majority shareholder owes a fiduciary duty to minority shareholders. ${ }^{7}$ To be sure, in specific contexts, the precise meaning of fiduciary obligation sometimes resists clear definition and varies noticeably among jurisdictions. All the same, it is noteworthy that recent Canadian developments reject the imposition of fiduciary constraints, however defined, upon the majority shareholder. In Brant Investments Ltd. v. KeepRite

6. See, e.g., Canadian Business Corporations Act, R.S.C. ch. C-44, \& 241 (1985) [hereinafter CBCA]; Ontario Business Corporations Act, R.S.O. ch. 4, \& 247 (1982) [hereinafter OBCA].

A majority of jurisdictions in the United States now also have provisions in corporation statutes that treat oppression as a basis on which a shareholder may petition for involuntary dissolution of the corporation. Three basic points about oppression may be of assistance. First, the underlying concept lacks a standardized meaning in either statutory formulation or case law interpretations of statutory language. Some courts have interpreted oppression to require a showing of wrongful conduct or breach of fiduciary duty; others require a showing that the impugned conduct disappointed the petitioner's reasonable expectations. The Canadian statutes under discussion separately encompass conduct that unfairly prejudices or disregards the petitioner's interests. See F. HODGE O'NEAL \& ROBERT B. THOMPSON, O'NEAL'S OPPRESSION OF MINORITY SHAREHOLDERS $\$ 7.13$ (2d ed. 1991). Second, most oppression statutes protect only the interests of shareholders; the Canadian statutes are unusual in encompassing nonshareholder interests. See infra part IV.B. Third, most oppression statutes in the United States limit the relief available to the petitioner to dissolution or a judicially-supervised buy-out of the petitioner's interest in the corporation. The Canadian statutes authorize a broad range of remedies, including injunctive relief and money damages. See infra note 30. Additionally, Canadian courts have permitted oppression litigation when the impugned conduct primarily injured the corporation rather than requiring the action to be brought as a derivative suit, see infra text accompanying note 146.

7. The classic assertion of the proposition came in Pepper v. Litton, 308 U.S. 295 (1939), a bankruptcy case in which the Court made the following statement:

A director is a fiduciary. So is a dominant or controlling stockholder or group of stockholders. Their powers are in trust. Their dealings with the corporation are subjected to rigorous scrutiny .... [T] [Tat standard of fiduciary obligation is designed for the protection of the entire community of interests in the corporation-creditors as well as stockholders.

Id. at 306-07 (citations omitted). The question of duties owed to creditors is addressed in part IV infra. Some authorities resist use of the term "fiduciary" to characterize directors' and controlling shareholders' duties in a corporate context because they fear that the term will lead to a confused importation of obligations unique to trustees. See REviSED MODEl Bus. CORP. ACT $\$ 8.30 \mathrm{cmt} .1$ (1991) [hereinafter RMBCA]. 
Inc. ${ }^{8}$ the Ontario Court of Appeal held that other components of Canadian law made it unnecessary, and even "inappropriate," to impose a fiduciary obligation in favor of minority shareholders on majority shareholders or, for that matter, on directors. ${ }^{9}$ Instead, the court pointed to the breadth and generality of the remedy for oppression created by the Canada Business Corporations Act ("CBCA").

The question addressed by KeepRite is best understood as a component of a much larger question: whether it is appropriate or efficient to impose limits on a majority shareholder's powers. Controlling a majority of shares brings majority voting power on issues and transactions that require a direct shareholder vote. It also confers the power to elect a majority, and frequently all, of the corporation's directors. Once in office, the directors may well acquiesce to the desires of the controlling shareholder. Systems of corporate law have varied in the degree to which they constrain the acts of majority shareholders; presently, Canada and the United States impose a variety of legal limits on a majority shareholder's ability to obtain maximum advantage through his or her position. These limits fall into two general categories. The first category consists of statutory and case law rules that are applicable to defined types of transactions. These rules prohibit such transactions altogether, permit them only on closely circumscribed terms, or increase the cost ultimately borne by the corporation and its majority shareholders as a consequence of the transaction. The second category consists of general standards, formulated by statute or case law, applicable in litigation that challenges individual transactions or patterns of transactions. Putting aside technical detail in implementation for a moment, present Canadian law places noticeably more emphasis on rules in the first category than does U.S. law. ${ }^{10}$

Rules affecting share repurchases and various modes of share acquisition provide many illustrations of legally imposed constraints on majority shareholders. Through a repurchase, a majority shareholder may cause her own shares to be repurchased on attractive terms not available to the minority. Conversely, the majority shareholder may also cause the corporation to acquire the minority's interest at a price that compares unfavorably to the corporation's long-term prospects. Share repurchases have long been feasible in the United States, subject only to the insolvency and formal capital constraints imposed by corporation statutes. ${ }^{11}$ Repurchase transactions have been fertile ground in the United States for judicial elaboration of fiduciary constraints on controlling shareholders; some courts require that closely held corporations afford the same

8. 80 D.L.R.4th 161 (Ont. App. 1991).

9. Id. at $171-72$.

10. Other systems-in particular Great Britain and Australia-in turn diverge from Canada and the United States, as well as from each other.

11. Until relatively recently, corporations lacked power in the United Kingdom and Australia to repurchase their own shares on any terms, which obviated any need for rules regulating repurchase transactions. 
repurchase opportunities to all shareholders that are available to the majority. ${ }^{12}$ Fiduciary constraints also regulate, as explained below, ${ }^{13}$ the terms of transactions in which the corporation cashes out or otherwise eliminates the minority's equity investment.

Majority shareholders are also constrained by rules that require that an equal benefit be derived from a transaction. It is not unusual for a purchaser of a controlling block of shares to be willing to pay more, on a per share basis, to owners of the control block than to noncontrolling shareholders who are also willing to sell. ${ }^{14}$ Under the Ontario Securities Act, for example, a shareholder who sells a controlling interest may not receive a control premium that is not equally available on a per share basis to all shareholders. ${ }^{15}$ In the United States, although a controlling shareholder may incur liability as a fiduciary if the purchaser subsequently loots the corporation's assets, ${ }^{16}$ no general egalitarian norm applies to sales of control. Canadian law is more expansive than is U.S. law in defining the circumstances under which a minority shareholder has the right to compel the corporation to pay-out the fair value of her investment. ${ }^{17}$ Such rights are conventionally believed to constrain the majority by making it attractive to structure transactions so that a minimal number of minority shareholders demand their statutory right to a cash payment.

Statutory oppression remedies and fiduciary doctrines, in contrast, operate much more generally. Because the operative concepts of oppression and fiduciary duty are not precise, these doctrines do not operate with a high level of predictability. The doctrines facilitate close judicial scrutiny of the factual background of an impugned transaction or pattern of behavior. In evaluating the significant differences between fiduciary doctrine and oppression doctrine, it is important to note that the Canadian oppression legislation diverges in significant respects from counterpart legislation in the United States, Great Britain, and Australia. For example, the CBCA provision interpreted in KeepRite expressly recognizes the interests of nonshareholder constituents as interests appropriately vindicated through oppression litigation. Oppression legislation in Great Britain

12. See, e.g., Donahue v. Rodd Electrotype Co., 328 N.E.2d 505, 518 (Mass. 1975).

13. See infra text accompanying notes $82-87$.

14. The difference in price per share is conventionally termed a control premium. See ROBERT C. Clark, CORPORATE LAW $\$ 11.4$ (1986).

15. See Ontario Securities Act, 11 R.S.O. ch. S-5, $\$ \$ 93(1)(c), 95$ (1990) [hereinafter OSA]. The OSA exempts, inter alia, control transactions in which the price paid per share, including brokerage fees, does not exceed $115 \%$ of market value at the date of the bid. See id. $\$ 93(1)$ (c)(iii). In effect, the OSA tolerates unequal sharing of control premiums that do not exceed $15 \%$ ! The transactions tolerated, though, are likely to occur in relatively small corporations, for the OSA exemption is unavailable if more than five shareholders sell. See id. $\$ 93(1)(\mathrm{c})(\mathrm{i})$.

16. See Harris v. Carter, 582 A.2d 222, 233-35 (Del. Ch. 1990) (adopting rule that seller is liable if the circumstances would alert a reasonably prudent person to investigate the buyer rather than rule imposing liability only on seller with actual knowledge of buyer's improper purpose).

17. See infra note 24 . 
and Australia, in contrast, limits its scope to shareholder interests ${ }^{18}$ as do the more modest statutory oppression provisions in the United States. ${ }^{19}$

\section{B. Current Canadian Jurisprudence}

1. The KeepRite Transaction. KeepRite is a significant case for many reasons, among them the ordinariness of its facts. In KeepRite, two wholly owned subsidiaries of a parent corporation, Inter-City Gas Corporation (ICG), sold assets to a fifty-five percent-owned subsidiary (KeepRite), for a net purchase price of $\$ 19.5$ million. KeepRite manufactured and sold refrigeration and air conditioning equipment; it purchased assets, including inventory, previously used by the wholly owned subsidiaries in the manufacture and sale of heating equipment. Prior to the asset purchase, KeepRite was in financial difficulty due to several factors, prominent among them KeepRite's high debt-to-equity ratio and the short season for air conditioning in Canada. ${ }^{20}$ KeepRite skipped the fourth quarter dividend in 1982, exhausted its lines of credit by the end of 1982 , and needed an infusion of equity to complete a refinancing of its bank debt. Neither the trial court nor the appellate court opinion in KeepRite precisely identifies the author of the proposal that KeepRite purchase the heating assets from the wholly owned subsidiaries. The proposal involved financing the asset purchase through a rights offering of additional KeepRite equity to its present shareholders. Facilitating the rights offering, in turn, required an amendment to KeepRite's articles of incorporation to create preferred shares and to make unlimited the number of common shares authorized.

Once KeepRite's CEO raised the purchase proposal with the corporation's directors, the board appointed three independent directors to a separate committee to evaluate the proposal; no committee member had any employment ties or other affiliation with the parent corporation or its wholly owned subsidiaries. However, the members disagreed about the committee's mission. One member believed that the committee should consider the transaction as if it were an arm's-length deal. Thus, he felt that the committee should try to negotiate a lower purchase price for the assets and that the committee should remember that the sellers might obtain benefits through the transaction beyond their receipt of the purchase proceeds. ${ }^{21}$ Another committee member thought this approach was "too restrictive" and proposed that the committee evaluate whether the transaction was, all things considered, fair to KeepRite, given its financial predicament and the financing structure created by the rights

18. See Companies Act, 1985, ch. 6, $\$ 459$ (Eng.); Corporations Law $\S 260,1992$ (Austl.).

19. See infra note 30.

20. See Re Brant Invs. Ltd. and KeepRite, Inc., 42 D.L.R.4th 15, 21 (Ont. H. Ct. 1988). Some of KeepRite's customers also reacted adversely to its evolving relationship with ICG, which had acquired $64 \%$ of KeepRite's shares in 1982 through a takeover bid. Id. at 21-22.

21. Id. at 25-26. 
offering. ${ }^{22}$ Eventually, the committee, which met five times, achieved a reduction in the purchase price and, with the assistance of financial advisers, considered the synergistic benefits of the transaction to KeepRite. The committee did not, however, commission a valuation of the assets on a goingconcern basis. On the committee's affirmative recommendation, KeepRite's directors approved the asset acquisition, and a sufficient majority of its shareholders then approved the amendments necessary to facilitate the rights offering. The offering and the acquisition were subsequently completed.

The plaintiffs, minority shareholders representing about twenty-eight percent of KeepRite's shares, initially-and ultimately unsuccessfully-sought an injunction against the rights offering. The plaintiffs then attacked the asset acquisition under the CBCA section prohibiting an action that "is oppressive or unfairly prejudicial to or that unfairly disregards the interests of any security holder, creditor, director or officer ...."23 The plaintiffs also brought an action, as dissenting shareholders, to fix the value of their shares so that the shares' fair value could be paid out to them. ${ }^{24}$ The court held that the plaintiffs

22. See id. at 25.

23. The plaintiffs sued under CBCA $\$ 234$, now renumbered as $\S 241$.

24. The CBCA entitles a dissenting shareholder to payment of "the fair value" of her shares, "determined as of the close of business on the day before the resolution was adopted ..." from which the shareholder dissented. CBCA $\$ 190(3)$. A shareholder has the right to dissent from an amendment to the corporation's articles that would "add, change or remove any provisions restricting or constraining the issue, transfer or ownership of shares" in the class held by the shareholder. Id. $\& 190(1)$ (a). Removing a maximum limit on the number of authorized common shares may fall within $\S 190(1)(a)$ because such a limit controls the number of shares the corporation may issue. Additionally, and more directly, under CBCA \& 190(2) a shareholder may dissent if approval of the amendment requires a separate class vote by members of that shareholder's class of shares. Section 176(1)(a) requires a separate class vote to "increase or decrease any maximum number of authorized shares of such class, or increase any maximum number of authorized shares of a class having rights or privileges equal or superior to the shares of such class...."

Canadian corporation statutes contain much broader triggers for dissenters' rights than do counterpart provisions in the United States. The Delaware statute restricts dissenters' rights to transactions formally structured as mergers or consolidations. See DEL. CODE ANN. tit. 8, \& 262(b) (1974). California, more generously, mandates dissenters' rights in all reorganization transactions, defined by statute to include various modes of corporate fusion that are not formally structured as mergers, such as share exchanges and sales of all, or substantially all, of a corporation's assets. See CAL. CORP. CODE $\$ \S 181,1201,1300$ (West 1990). Unlike the CBCA, both the Delaware and California statutes contain exceptions to the availability of appraisal for shares with a liquid public market value. The Delaware statute, however, subjects this exception to a further exception for transactions in which shareholders receive consideration other than shares in the corporation surviving or resulting from the merger, shares in some other corporation with an active public market, cash in lieu of fractional shares, or some combination thereof. See DEL. CODE ANN. tit. 8, § 262(b). The Revised Model Business Corporation Act [hereinafter RMBCA], more expansively, also mandates dissenters' rights for selected types of amendments to a corporation's articles. See RMBCA \& 13.02(a)(4). In general, the triggers for these rights are more narrowly drawn than the amendment triggers in the CBCA. The amendments in KeepRite, for example, would trigger dissenters' rights under the RMBCA only if they created "a right in respect of redemption" for the preferred stock that "materially and adversely affect[ed] rights in respect of the dissenter's shares ...." Id. $\$ 13.02(\mathrm{a})(4)(\mathrm{ii})$. The fact that an amendment requires a separate class vote, see id. $\$ 10.04$, does not in itself trigger dissenters' rights under the RMBCA.

The CBCA provisions defining dissenters' rights were patterned after the North Carolina Business Corporation Act, which in 1925 was one of the first statutes to create rights of dissent and appraisal. See Russell M. Robinson II, North Carolina Corporation LAw AND PraCtice \& 27-1 (3d ed. 1990). The North Carolina statute was viewed as more progressive on the topic than the original Model 
failed to establish grounds necessary to recover under the oppression statute. However, the court held that the plaintiffs independently had a right to dissent and, thus, to receive the fair value of their shares.

2. The KeepRite Transaction Analyzed under the Oppression Statute. The generality of oppression statutes makes it difficult to delineate, in analytic form, the constituent elements of conduct that violates the statute. The origins of Canadian oppression remedies are readily traceable to provisions in the English companies acts. ${ }^{25}$ Canadian statutory language, however, clearly expands the grievances well beyond the "oppressive" acts and omissions covered by the initial English provisions. The CBCA encompasses the corporation's own acts or omissions, the conduct of its business, and the exercise of its directors' powers. A complainant may seek relief based on corporate acts and omissions that are "unfairly prejudicial to or that unfairly disregard the interests of any security holder, creditor, director or officer . . ." ${ }^{26}$ The operative definition of unfairness is thus not inexorably linked to the actor's motives or intentions. ${ }^{27}$ Indeed, the KeepRite court's analysis of the CBCA oppression remedy notes that its expansive language obviates the need for the complaining party to submit evidence that any bad faith or want of probity accompanied the disputed acts. ${ }^{28}$ As a result, interests may be "unfairly" disregarded or prejudiced by acts or omissions of well-intentioned persons. Motive is not irrelevant, though. According to KeepRite, evidence of "quality" or "propriety" of the conduct complained of is clearly relevant" in determining whether the conduct is oppressive or unfair. ${ }^{29}$ As we shall see, however, many more questions lie in wait on the fairness front. ${ }^{30}$

Business Corporation Act. See id. In particular, its protections for class shareholders commended it to the Canadian drafters. See Robert W.V. Dickerson et al., Proposals for a New Business CORPORATIONS LAW FOR CANADA 118 (1971).

25. For comprehensive histories, see Brian Cheffins, The Oppression Remedy in Corporate Law: The Canadian Experience, 10 U. PA. J. INT'L BUS. L. 305 (1988); Jeffrey G. MacIntosh, Minority Shareholder Rights in Canada and England: 1860-1987, 27 OsGOODE HALL L.J. 561 (1989).

26. CBCA, R.S.C. ch. C $-44, \S 241$ (2). The coverage of the oppression provision under the Ontario Business Corporations Act (OBCA) is broader. Under the OBCA, an act or omission that "threatens to effect a result ... that is oppressive or unfairly prejudicial to or that unfairly disregards the interests of any security holder, creditor, director or officer ..." may be challenged. See OBCA, R.S.O. ch. 4, $\$ 247(2)(1982)$. The CBCA on its face is limited to an act or omission that has the proscribed effect, as opposed to one that simply "threatens" such an effect. Cf. Bank of Montreal v. Dome Petroleum Ltd., 54 Alta. L.R. 2d 289, 299-301 (Q.B. 1987) (rejecting creditor's application on basis of its anticipatory nature).

27. See Jeffrey G. MacIntosh, Bad Faith and the Oppression Remedy: Uneasy Marriage, or Amicable Divorce, 69 CAN. BAR REv. 276, 297 (1990) (arguing that courts often embrace an objective theory centered on unfair result rather than requiring plaintiffs to show bad faith).

28. See Brant Invs. Ltd. v. KeepRite, 80 D.L.R.4th 161, 176-81 (Ont. App. 1991).

29. Id. at 178 .

30. Canadian oppression statutes authorize a broad range of remedies, including orders to restrain the conduct complained of, orders for compensation, orders to direct the purchase of securities, and orders to annul a corporation's articles or bylaws. In no way is the court's remedial power defined by or limited to an order for involuntary dissolution. CBCA, R.S.C. ch. C-44, § 241(3) (authorizing court to "make any interim or final order it thinks fit"; specific remedies delineated in statute are not exclusive). Similarly, the oppression provision adopted by the English Companies Act authorizes the 
The trial court in KeepRite appears to have examined broadly the nature of the challenged transaction, the manner in which it was carried out, and its result. $^{31}$ The trial court was not persuaded that the transaction was favorable to ICG at the expense of KeepRite. ${ }^{32}$ Although, during the trial, the respondents assumed the burden of adducing evidence on these questions, the appellate court in KeepRite declined to determine whether, in all such transactions, the majority shareholder must bear the burden of persuasion. ${ }^{33}$ In oppression actions generally, the burden of persuasion is on the applicant. ${ }^{34}$

The appellate court's opinion in KeepRite also lacks a clear statement of the proper role of the independent committee. Although the opinion details, at some length, the activities of the KeepRite committee, it articulates no general goal or set of functions for such a committee. Indeed, the committee's principal economic accomplishment-achieving a reduction in the net purchase price KeepRite paid for the assets -is discernible in the appellate opinion only by implication. Moreover, the appellate opinion seems to envision a relatively constrained role for the trial court in reviewing the transaction and the committee's role:

There can be no doubt that on an application under [the oppression section] the trial judge is required to consider the nature of the impugned acts and the method in which they were carried out. That does not mean that the trial judge should substitute his own business judgment for that of managers, directors, or a committee such as the one involved in assessing this transaction. ${ }^{35}$

KeepRite does not resolve the question of whether its refusal to permit judicial "substitution" of business judgment constitutes a requirement of deference to committees like the one in KeepRite.

The broad and undefined bases for liability under the oppression statute render the imposition of fiduciary duty "unnecessary and ... inappropriate,"

court to "make such order as it thinks fit for giving relief in respect of the matters complained of." Companies Act 1985, ch. 6, § 461(1) (Eng.).

In contrast, corporation statutes in the United States, to the extent that they include oppression as a basis for relief, treat it as a basis for involuntary dissolution in a petition brought by a shareholder. See, e.g., RMBCA \& 14.30(2)(ii) (allowing court-ordered dissolution if shareholder establishes in a proceeding that directors or those in control of the corporation "have acted, are acting, or will act in a manner that is illegal, oppressive or fraudulent"). See generally F. HODGE O'NEAL \& ROBERT B. THOMPSON, O'NeAL'S OPPRESSION OF MINORITY SHAREHOLDERS: PROTECTING MINORITY RightS IN SQUEEZE-OUTS AND OTHER INTRACORPORATE CONFLICTS $\$ 7.13$ (2d ed. 1991). In about half of the states, a buyout of the complainant's holdings is an alternative remedy. Some states limit the buyout remedy to closely held corporations. See $i d$. $\$ 7.19$. The RMBCA limits the buyout alternative to corporations with no shares listed on a national securities exchange or traded by members of a national securities association. See RMBCA \& 14.34(a). Under the Close Corporations Supplement to the RMBCA, the court has broad remedial jurisdiction in an oppression action, comparable to that created by the CBCA. See MODEL STAT. ClOSE CORP. SUPP. \& 41. The Delaware corporation statute contains no oppression provision.

31. See KeepRite, 80 D.L.R.4th at 183.

32. See Re Brant Invs. Ltd. and KeepRite Inc., 42 D.L.R.4th 15, 41-42 (Ont. H. Ct. 1988).

33. See KeepRite, 80 D.L.R.4th at $\mathbf{1 8 3}$.

34. See, e.g., In re Ferguson and Imax Sys. Corp., 150 D.L.R.3d 718, 728 (Ont. App. 1983).

35. KeepRite, 80 D.L.R.4th at 190. 
according to the appellate opinion in KeepRite. ${ }^{36}$ The court reasoned that such an imposition is unnecessary because the statutory oppression scheme is so broadly cast that "the evidence necessary to establish a breach of fiduciary duty would be subsumed in the broader range of evidence which would be appropriately adduced on an application under the section." 37 The court felt that imposing a fiduciary duty would be inappropriate because the CBCA, like other Canadian corporation statutes, contains an articulation of the duty owed to the corporation by each director and officer to "act honestly and in good faith with a view to the best interests of the corporation ...."38

However, the oppression statute expressly includes the interests of persons other than the corporation itself. Thus, "[t]o impose upon directors and officers a fiduciary duty to the corporation as well as to individual groups of shareholders ... could place directors in a position of irreconcilable conflict, particularly in situations where the corporation is faced with adverse economic conditions." ${ }^{39}$ In this passage, the court seemed to ignore the separate position of the majority shareholder, focusing instead solely on the posture of its directors. The crucial question is whether the majority shareholder itself should be treated as a fiduciary of minority shareholders in the subsidiary, not the fiduciary posture of its or the subsidiary's directors. Interestingly, the KeepRite opinion holds out the prospect that, on other facts, a majority shareholder might owe fiduciary duties to the minority. Everything turns on a particularistic and fact-specific investigation; "[c]ourts impose fiduciary duties only in situations where someone stands in a particular position of trust by virtue of an agreement or as a result of the circumstances and relationship of the parties." 40 Accordingly, one suspects that longstanding relationships among shareholders of small corporations could be analyzed differently. ${ }^{41}$ For mundane transactions in larger ventures, like KeepRite, fiduciary standards do not apply.

The precise reach of the oppression remedy, however broad, may leave gaps. For example, would an oppression standard catch insider trading? More generally, if the defendant's acts produced a benefit for her without demonstrably injuring someone else, fiduciary principles permit recovery of the benefit if it was ill-gotten. The question under an oppression analysis, in contrast, is whether the defendant's acts unfairly prejudiced or disregarded someone's interests.

36. Id. at 172 .

37. Id.

38. Id. (emphasis in original) (quoting CBCA, R.S.C. ch. C-44, $\$ 117(1)$ ).

39. Id.

40. Id.

41. Coleman v. Myers, [1977] 2 N.Z.L.R. 225 (1976), is a Commonwealth example. In Coleman, the defendants, a father and son who ran a family corporation, made a takeover bid for the shares owned by other family members without disclosing the son's financing plans for the bid and the son's knowledge that the company's assets were worth far more than their book value. The New Zealand Court of Appeal held that both defendants, who were directors, breached a fiduciary duty owed to the non-insider shareholders, a duty based on the confidence reposed in the father and son by the other shareholders. 
In short, the KeepRite opinion does not contribute much clarity to oppression jurisprudence, apart from its holding that a controlling shareholder's status does not in itself make that shareholder a fiduciary toward minority shareholders. Otherwise KeepRite omits or muddles resolution of key matters. KeepRite does not allocate the burden of proving (or disproving) fairness. Although the opinion does not define functions or objectives for a committee of unaffiliated directors, it appears to contemplate judicial deference to the committee's business judgment. KeepRite, finally, seems to equivocate about the relevance of the defendant's subjective motives: The applicant need not establish bad faith on the defendant's part, while the quality or propriety of her conduct bears on whether it was oppressive or unfair. ${ }^{42}$

3. Rationales and Limits for Oppression Statutes. Canadian courts have been receptive to the application of fiduciary standards in a broad range of noncorporate contexts, ${ }^{43}$ with a degree of enthusiasm that startles observers elsewhere in the British Commonwealth. ${ }^{44}$ Indeed, prior to the Court of Appeal's opinion in KeepRite, well-regarded Canadian commentators emphasized the appropriateness of applying fiduciary constraints to majority shareholders. ${ }^{45}$ Professor MacIntosh, in particular, argued that the oppression statute itself imposed a de facto fiduciary duty on controlling shareholders. ${ }^{46}$ The Ontario Securities Commission ("OSC"), resolving a takeover-generated dispute, expressly assumed that nonmajority, controlling shareholders were fiduciaries toward the minority, an assumption the OSC based, in part, on perceived signals from Ontario courts. ${ }^{47}$ Finally, the report accompanying the statutory draft upon which contemporary Canadian corporation statutes are based justifies the scope of the oppression remedy with the "premise that dominant shareholders, who are in a position to control management, owe a fiduciary duty to minority shareholders comparable to the duty that directors and officers owe to the corporation. ${ }^{248}$ But agreement on this point is far from unanimous. ${ }^{49}$

42. In contrast, if a fiduciary acts with benevolent motives in breaching a duty, the benevolence is not a defense. See Lacos Land Co. v. Arden Group, Inc., 517 A.2d 271, 278 (Del. Ch. 1986) (corporate fiduciary had no right to threaten acts that would breach duty to corporation, "even if benevolently motivated in doing so").

43. See generally Peter D. Maddaugh \& John C. MCCamus, The Law of Restitution 576-87 (1990) (analyzing leading Canadian cases).

44. Reportedly, the Chief Justice of Australia's High Court told the Chief Justice of the Canadian Supreme Court that "he understood that in Canada there were only three classes of people; those who are fiduciaries; those who are about to become fiduciaries; and judges." Earl A. Cherniak, Comment on Paper by Professor Jeffrey G. MacIntosh, in LAW SOCIETY OF UPPER CANADA: SPECIAL LeCTURES 1990: FIDUCIARY DUTIES 275 (1991).

45. See Jeffrey G. MacIntosh, The Puzzle of Shareholder Fiduciary Duties, 19 CAN. BUS. L.J. 86, 86 (1991).

46. See MacIntosh, supra note 25, at 636 ( $[$ [T]he oppression remedy has been applied by the courts to impose duties of a fiduciary character on majority or controlling shareholders ....").

47. Re C.T.C. Dealer Holdings Ltd. and Ontario Sec. Comm'n, 59 O.R.2d 79 (Div. Ct. 1987) (affirming OSC). The OSC's opinion cites for its principal support Goldex Mines Ltd. v. Revill, 7 O.R.2d 216 (C.A. 1975).

48. DICKERSON ET AL., supra note 24 , at 165. 
The history of oppression statutes, and circumstances elsewhere in corporate law to which this statutory remedy was designed to respond, help to explain KeepRite, if not the ultimate sources of a "last bastion" sensibility. ${ }^{50}$ The Canadian oppression statutes are expressly based on English counterpart provisions although, as noted above, they represent expansions on several fronts beyond the original English models. Likewise, Canadian corporate law could not have been immune to the strong majoritarian tradition so long and so deeply entrenched in English company law. ${ }^{51}$ Prior to 1948, minority shareholders in English companies were, as a practical matter, without much of a remedy against overreaching or opportunistic behavior by majority shareholders. An ill-defined doctrine of "fraud on the minority" possibly applied to extreme misbehavior. ${ }^{52}$ The minority shareholder could also petition the court to wind up the corporation on the ground that it was "just and equitable" to do so. Short of the drastic winding up remedy, minority shareholders were likely to be without recourse. Other procedural inhibitors, such as the rule in Foss v. Harbottle, ${ }^{53}$ which barred shareholder derivative actions and other shareholder actions arising from breaches of duty ratifiable by a majority of shareholders, greatly reduced the number of minority shareholder actions. ${ }^{54}$ English courts held that they lacked jurisdiction to interfere in the internal management of companies; some English opinions posited that shareholders, having elected weak-willed, incompetent, or foolish directors, were at fault when the consequences of their poor selections became evident! $!^{55}$

The English Companies Act of 1948 included an oppression statute that permitted the court to order remedies other than an order to wind up the company. When the petitioner could establish that the company's affairs were being conducted in an oppressive manner and that the facts would justify a winding up order, but that winding up would unfairly prejudice the parties, the court had the power to order an alternative remedy. However, the alternative remedy was not popular with the court. English commentators report only two successful petitions between 1948 and $1980 . .^{56}$ Amendments to the statute

49. See, e.g., Exco Corp. v. Nova Scotia Sav. \& Loan Co., 78 N.S.R.2d 91, 161 (N.S. Sup. Ct. 1987) (observing that " $[\mathrm{i}] \mathrm{t}$ is trite to say that shareholders do not owe to other shareholders anything akin to a fiduciary duty").

50. Fiduciary doctrine pervades Canadian law to such an extent that one commentator noted that "the conventional wisdom (which of course is always wrong) [is] that the last bastion of resistance to this sweep of the fiduciary juggernaut was the principle that there was no fiduciary duty between shareholders, majority control being absolute." See Cherniak, supra note 44, at 276.

51. See Jennifer Hill, Protecting Minority Shareholders and Reasonable Expectations, 10 COMPANY \& SEC. L.J. 86 (1992) (tracing history of majoritarian tradition in English company law).

52. See LAURENCE C.B. GOWER, MOdERN COMPANY LAw 593-603 (5th ed. 1992).

53. 67 Eng. Rep. 189 (1843).

54. See generally Stanley M. Beck. The Shareholders' Derivative Action, 52 CAN. BAR REV. 159 (1974).

55. Turquand v. Marshall, 4 L.R.-Ch. App. 376, 386 (1869), draws an especially low watermark; the Court observed that "however ridiculous and absurd [the directors'] conduct might seem, it was the misfortune of the company that they chose such unwise directors ...."

56. GOWER, supra note 52, at 663 n.3. 
subsequently eliminated the link to winding-up and replaced the requirement of oppressive conduct with the requirement that the conduct complained of be "unfairly prejudicial to the interests of some part of the members . . . "57

Despite the adoption of the expanded statute, English cases continue to restrict its reach in key respects. The petitioner must establish, for example, injury to members' interests as shareholders, ${ }^{58}$ which excludes typical situations in which controlling shareholders exclude a minority shareholder from the board of directors or from employment. Although Canadian courts, applying more broadly defined oppression statutes, have not imported the English restrictions, ${ }^{59}$ the normative backdrop of majoritarianism is inescapable. In other words, the enactment of broad oppression legislation in Canada facilitated a shift-indeed perhaps a metamorphosis-in judicial perspectives on the prerogatives of majority shareholders; ${ }^{60}$ the speed and acuity with which courts develop more particular doctrine under the broad statutory aegis turn on factors beyond the statute itself. The infrequency of litigation and the relative youth of the doctrine may be significant factors. The CBCA, along with its broad oppression provision, was enacted in 1975. Aspects of Canadian law appear to inhibit oppression suits by small shareholders: Attorneys may not represent clients in litigation on a contingency fee basis, ${ }^{61}$ and losing litigants are generally liable for the winner's costs, including attorneys' fees. ${ }^{62}$

All these circumstances combined make it difficult to predict the longevity or force of the KeepRite holding. However, KeepRite's rejection of the proposition that controlling shareholders are, as such, fiduciaries toward the minority does not stand alone in Canadian jurisprudence; much of Canada's corporate law reflects the entrenched strength of the majoritarian tradition derived from English company law. Additionally, but probably less substantively, the factors that inhibit some types of oppression litigation may also serve to thwart the metamorphic potential of the oppression statutes themselves.

\section{III}

\section{FIDUCIARY DOCTRINE CONTRASTED WITH NORMS APPLIED IN OPPRESSION CASES}

Does it matter whether transactions like the KeepRite asset purchase are, as in the United States, evaluated within an analytic framework defined by fiduciary concepts rather than the analytic framework established under the Canadian oppression statutes? On the specific facts of the KeepRite dispute, the answer

57. See Companies Act 1985, ch. 6, \& 459 (Eng.).

58. See, e.g., $\operatorname{Re}$ a Company, [1983] 2 All E.R. 36, 44.

59. See, e.g., Diligenti v. RWMD Operations Kelowna Ltd., [1976] 1 B.C.L.R. 36 (S. Ct.).

60. See MacIntosh, supra note 45 , at 130.

61. See, e.g., Solicitors Act, 11 R.S.O. ch. S.15, \& 28 (1990).

62. See, e.g., Courts of Justice Act, 2 R.S.O. ch. C.43, $\$ 131(1)$ (assessment of costs within court's discretion, subject to specific provision in statute or rules); Solicitors Act, 11 R.S.O. ch. S.15, $\$ \$ 20,36$ (costs not to be affected by special fee agreement between solicitor and client or by solicitor's salaried status). 
to this question may be beside the point, but, in general, the choice of analytic framework matters greatly.

These types of transactions raise two basic questions, which in turn suggest a number of corollary questions. First, did the process leading to the transaction's approval have problematic aspects? If noncontrolling shareholders voted to approve the transaction, were they sufficiently informed and free from coercion? If, as in KeepRite, the subsidiary had independent or unaffiliated directors who participated separately as a committee, what should be expected of the committee? Second, under what circumstances should the court evaluate the merits of the transaction? Should the court defer to the unaffiliated directors' judgment? What weight should be attached to the minority shareholders' vote of approval? If the court evaluates the transaction, what standard should it apply?

For a variety of reasons, resolving these questions through the fiduciary framework is likely to lead to crisper answers. Even as Canadian oppression jurisprudence "fills in," it is likely to retain the relative lack of definition evidenced by KeepRite. In particular, as explained below ${ }^{63}$ fiduciary analysis produces a more explicit and sharper definition for the role of the independent committee. However elusive its ultimate reach, conventional fiduciary analysis enables a court to identify the exclusive or primary beneficiary on behalf of whom decisionmakers must exercise discretion. In contrast, the focus on a statutorily undefined concept of fairness, as dictated by the Canadian oppression statutes, when coupled with the variety of interests that may be vindicated through these statutes, will generate answers that are more muted and less sharply defined.

\section{A. Fiduciary Constraints Applied to Controlling Shareholders}

Under U.S. law, to state that a majority or controlling shareholder is a fiduciary to minority shareholders is simply to begin the analysis. ${ }^{64}$ Cases

63. See infra part III.A.6.

64. Justice Frankfurter's opinion in SEC v. Chenery Corp., 318 U.S. 80, 85-86 (1943), contains the oft-quoted observation that to say that a person is a fiduciary "only begins analysis; it gives direction to further inquiry. To whom is he a fiduciary? What obligations does he owe as a fiduciary? In what respect has he failed to discharge these obligations? And what are the consequences of his deviation from duty?" To be sure, in some contexts the ensuing analysis may proceed expeditiously because the parties' relationship is such that the content and object of the fiduciary's obligations, and the consequences of breach, are governed by well-settled legal principles. See Austin W. Scott, The Fiduciary Principle, 37 CAL. L. REV. 539, 541 (1949) (describing the "usual fiduciary relations").

It may be that Canadian analysis of fiduciary questions is more structured than is its counterpart in the United States. Justice Frankfurter's observation serves as a starting point for many judicial opinions and much academic commentary produced in the United States. The judicial task, in short, is not simply to identify persons and fiduciaries and then subject them to a package of standardized and precisely defined duties; the task often encompasses the construction of the duties applicable to any given individual or type of fiduciary. The constructive element is especially visible when a fiduciary-such as a majority shareholder-has interests of her own that she may legitimately pursue, at least to some extent. Canadian writers, in contrast, may expect a higher degree of standardization in the duty's content, or may be less comfortable with express judicial construction, or may be working within a system that is at an earlier point in its development. Cf. Ronald G. Slaght, Proving a Breach of 
defining the content of the majority's fiduciary duty involve differing types of transactions and corporations. Not surprisingly, the cases are distinctive in some respects but, in others, develop definitions of duty that overlap. For present purposes, these cases can be placed in three basic categories: (1) cases involving an ongoing relationship between parent and subsidiary corporations where there are either direct business dealings between the parent and subsidiary or decisions having different impacts on the parent and the subsidiary's minority shareholders; (2) cases involving a transaction that eliminates the investment interest of minority shareholders in a subsidiary, leaving the parent or a wholly owned subsidiary as the owner of all equity in the subsidiary; ${ }^{65}$ and (3) cases involving a variety of transactions and practices within closely held corporations that are either advantageous to the majority shareholder or disadvantageous to the minority. While courts apply similar principles to the first two categories of cases, the last category raises concerns distinctive to closely held businesses.

The principal consequence of characterizing a controlling shareholder as a fiduciary is that her dealings with the subsidiary, if challenged by a minority shareholder of the subsidiary, may be reviewed by the court under a standard of "intrinsic fairness." 66 Although later cases tend to use the term "entire fairness," ${ }^{67}$ the terminology seems to be interchangeable. ${ }^{68}$ If the shareholder owns less than a majority of the shares, the plaintiff has the burden of establishing that the allegedly controlling shareholder dominated the directors or otherwise dictated the terms of the impugned transaction. ${ }^{69}$ In the absence of such a showing, courts defer to the exercise of business judgment of controlling shareholders and directors ${ }^{70}$ unless the plaintiff establishes that the

Fiduciary Duty, in Law Society of UpPER CaNAda: SPECIAL Lectures 1990: Fiduciary Duties, 37, 45 (1991) (expressing optimism about the development of established standards to permit identification of aspects of bank-customer relationship that warrant fiduciary obligation).

65. In a further subset of transactions, the minority receives cash or debt securities as consideration in the merger, rather than an equity interest in a surviving corporation.

66. See, e.g., Sinclair Oil Corp. v. Levien, 280 A.2d 717, 720 (Del. 1971).

67. See, e.g., Weinberger v. UOP, Inc., 457 A.2d 701, 710 (Del. 1983).

68. See id. (when self-dealing, directors "are required to demonstrate their utmost good faith and the most scrupulous inherent fairness of the bargain. The requirement of fairness is unflinching in its demand that where one stands on both sides of a transaction, he has the burden of establishing its entire fairness ...." (citation omitted)).

69. See Puma v. Marriott, 283 A.2d 693 (Del. Ch. 1971) (holding that plaintiff failed to make any showing that $46 \%$ shareholder dominated unaffiliated directors of corporation or dictated terms of stock acquisition transaction). Older Delaware cases required the plaintiff to demonstrate that a majority shareholder "stood on both sides of the transaction and . . dictated its terms," while more recent authority requires only a showing that the parent stood on both sides of the transaction. See Citron v. E.I. DuPont de Nemours \& Co., 584 A.2d 490, 500 n.13 (Del. Ch. 1990). The fact that the parent did not dictate the transaction's terms is, in more recent cases, evidence that the parent dealt fairly with minority shareholders. Id. See also Rosenblatt v. Getty Oil Co., 493 A.2d 929, 938 (Del. 1985) (bargaining over merger ratio between parent and subsidiary had arm's-length quality).

Control also emerges as an issue when a plaintiff in a derivative suit seeks to excuse her failure to make demand on the corporation's directors. See infra text accompanying notes 156-61.

70. See Price v. Standard Oil Co., 55 N.Y.S.2d 890, 896 (Sup. Ct. 1945). 
transaction was tainted by fraud ${ }^{71}$ or that it was tantamount to a gift of the subsidiary's assets. ${ }^{72}$ Business judgments are presumed to be sound and beyond the sphere of judicial review if they can be attributed to any rational business purpose. $^{73}$ Although distinguished commentators have argued that " $[t]$ he results of the cases suggest that the difference between the two standards is not significant,"74 defendants regularly resist the application of the intrinsic fairness standard, knowing well the length of litigation and breadth of judicial review that the standard invites. Indeed, the same commentators suggest that the choice of standard $\longrightarrow$ or the choice of label for a standard-has a greater ex ante impact on behavior than its ex post impact in litigation. ${ }^{75}$ In other words, knowing that the transaction will be closely reviewed by a court if it is challenged in litigation will cause those involved to behave more cautiously in connection with the transaction.

1. The Selfish Parent. Cases that articulate the intrinsic fairness standard acknowledge that the parent corporation is not under a duty to engage in selfless behavior or to sacrifice to benefit the subsidiary. In general, a shareholder may vote and control her shares in her own interest; a shareholder is free to vote on the basis of a desire for personal profit or on the basis of whim or caprice. ${ }^{76}$ The intrinsic fairness standard does not limit the parent's freedom to elect directors or to approve fundamental transactions. ${ }^{77}$ The parent's directors are also bound by a fiduciary obligation to serve the parent's interests. Thus, they need not structure every relationship with the subsidiary, or every transaction that affects the subsidiary, with an eye solely on furthering the interests of the subsidiary's minority shareholders. ${ }^{78}$ Indeed, to do so would be inconsistent with the directors' duty to the parent corporation and its own shareholders. The

71. See Davis v. Louisville Gas \& Elec. Co., 142 A. 654, 659 (Del. Ch. 1928) (finding judgment of directors final absent showing of fraud).

72. See Sinclair Oil, 280 A.2d at 720 (only showing of "gross and palpable overreaching" will lead court to interfere with directors' business judgment).

73. See, e.g., Schreiber v. Pennzoil Co., 419 A.2d 952, 956 (Del. Ch. 1980). In contrast, if the defendants concede that their actions were inexplicable, then they will fall outside the business judgment rule. See Selheimer v. Manganese Corp. of Am., 224 A.2d 634, 646 (Pa. 1966).

74. See Victor Brudney \& Marvin A. Chirelstein, Fair Shares in Corporate Mergers and Takeovers, 88 HARV. L. REV. 297,318 n.49 (1974).

75. Id. In particular, Professors Brudney and Chirelstein acknowledge the possibility that such an articulation "inhibits those who negotiate parent-subsidiary mergers more than those who corrupt 'independent' management with side payments." Id.

76. See Bershad v. Curtiss-Wright Corp., 535 A.2d 840, 845 (Del. 1987) (acknowledging that shareholders may vote based on whatever motive they choose as long as they do not violate fiduciary obligation to other shareholders).

77. Indeed, as the cases under discussion amply illustrate, the parent may breach its fiduciary obligation through a transaction that does not directly entail any use of the parent's voting power. See, e.g., Sinclair Oil Corp. v. Levien, Del., 280 A.2d 717 (1971) (causing subsidiary to breach contract may constitute breach of fiduciary obligation by parent). Nor is the use or threatened use of voting power always essential to an oppression claim. See Scottish Coop. Wholesale Soc'y Ltd. v. Meyer, [1958] 3 All E.R. 66 (H.L.).

78. See Ewen v. Peoria \& E. Ry. Co., 78 F. Supp. 312, 316 (S.D.N.Y. 1948) (finding that parent only owed subsidiary duty not to discriminate against it). 
cases implicitly-and in some instances explicitly-recognize that the parent corporation's relationship with the subsidiary will optimally yield results that resemble those generated by negotiations and dealings between parties operating at arm's length. ${ }^{79}$

The intensity and scope of the parent's fiduciary duty to the subsidiary's minority shareholders are not readily comparable to the inhibitions conventionally imposed by the law on other types of fiduciaries. A simple example is the fiduciary's self-investment of the beneficiary's funds. In the absence of statutory authorization, fiduciaries such as trustees and guardians may not self-invest, even if the investment does not produce a demonstrable loss for the beneficiary, because self-investment creates an obvious conflict of interest for a fiduciary institution. ${ }^{80}$ In contrast, if a subsidiary "deposits" its cash with its parent corporation, and receives a competitive interest rate in return, the parent has not breached its fiduciary obligation to the subsidiary. ${ }^{81}$

Other examples of the parent's right not to act selflessly arise in connection with cash-out merger transactions, which terminate the minority's equity investment in the subsidiary and do not continue it in a surviving corporation. The parent is not under an obligation to sell its majority shareholding in the subsidiary to a third party, even if the sale would be advantageous to the minority because of the attractive price minority shareholders would receive for their shares. ${ }^{82}$ In negotiating the terms of a merger of the subsidiary into the parent (or into a wholly owned subsidiary), the parent's fiduciary obligation does not oblige it to disclose the top price it is willing to pay to the directors negotiating on behalf of the subsidiary or to the subsidiary's minority shareholders. ${ }^{83}$ This follows from a stockholder's right to sell her stock when and on such terms as she deems expedient. ${ }^{84}$ Likewise, the parent need not disclose projections and analyses respecting the subsidiary developed by or on behalf of the parent, ${ }^{85}$ unless the projections and analyses are prepared by directors of the subsidiary who are also in fiduciary positions with the parent. ${ }^{86}$ On the other hand, the parent's duty of complete candor to the minority requires it to

79. See id. at 316-17.

80. See, e.g., In re Estate of Swiecicki, 477 N.E.2d 488, 490 (III. 1985) (prohibiting guardian from reaping any benefit from self-investment of ward's funds).

81. See Burton v. Exxon Corp., 583 F. Supp. 405, 420-21 (S.D.N.Y. 1984).

82. See Bershad, 535 A.2d at 845.

83. See Rosenblatt v. Getty Oil Co., 493 A.2d 929, 939 (Del. 1985).

84. See Harris v. Carter, 582 A.2d 222, 234 (Del. Ch. 1990) (requiring only good faith in shareholder's sale of stock).

85. See Rosenblatt, 493 A.2d at 938-39 (earnings projection for subsidiary prepared by parent need not be disclosed to subsidiary in merger negotiations, since no evidence that projections were "material"); cf. Citron v. E.I. DuPont de Nemours \& Co., 584 A.2d 490, 504-05 (Del. Ch. 1990) (parent's internally generated valuation of subsidiary not material for purpose of disclosure to shareholders); Rabkin v. Olin Corp., [1990 Transfer Binder] Fed. Sec. L. Rep. (CCH) 9 95,255 (Del. Ch. Apr. 17, 1990) (internal planning document prepared by staff member on his own initiative, which was not seen by parent's board, does not establish that parent had a long-standing plan to cash out minority).

86. See Weinberger v. UOP, Inc., 457 A.2d 701, 708-09 (Del. 1983) (projections of price at which elimination of minority constituted "outstanding investment opportunity" for parent prepared by two directors of subsidiary who were also directors of parent deemed material). 
disclose information within its possession that might aid the minority in evaluating the merger. $^{87}$

2. The Parent Corporation's Duties Contrasted with Those of the Subsidiary's Directors. Unlike the KeepRite opinion, U.S. cases carefully differentiate between the fiduciary duties owed by the parent corporation itself and duties owed by directors serving either that corporation or the subsidiary. Subsidiary directors who participate in the conduct or the transaction challenged by the plaintiff must satisfy the intrinsic fairness standard if they also occupy a fiduciary position with the parent corporation. ${ }^{88}$ Subsidiary directors who are dual fiduciaries but who do not participate in the decision leading to the transaction are not vulnerable to any claim by the plaintiff. ${ }^{89}$ Unaffiliated directors who participate in the decision, such as the directors on the committee in KeepRite, are not dual fiduciaries. Thus, if they exercise due care ${ }^{90}$ and act in good faith, ${ }^{91}$ their conduct is subject to review under the business judgment standard. $^{92}$

The fiduciary status of the parent corporation and the applicable standard of judicial review are questions separate from inquiries about directors as individual defendants. These questions overlap only to the extent that the parent argues that it did not exercise its control, that is, that the interests of minority shareholders were effectively represented by subsidiary directors so that the parent did not dictate the terms of the transaction. ${ }^{93}$ It is also apparent in these cases that the interests to be protected through fiduciary standards are those of minority shareholders of the subsidiary. Fiduciary standards embody stringent expectations, operating narrowly, within closely drawn borders. Delaware cases, for example, exclude from the scope of fiduciary protection the contractually defined rights of bondholders and other creditors, ${ }^{94}$ the rights of holders of

87. See Kahn v. Household Acquisition Corp., 591 A.2d 166, 171 (Del. 1991). It is entirely possible that on some level Kahn conflicts with the holding in Rosenblatt that the parent's fiduciary duty does not oblige it to disclose its top price to directors negotiating on behalf of the subsidiary or to the subsidiary's shareholders. See supra text accompanying note 82 . Information about that price seems highly pertinent to evaluation of the merger by the subsidiary's shareholders and thus to be encompassed by the parent's obligation of complete candor. As it happens, the information in Kahn, which concerned government subsidies, was held by the court not to be material, see Kahn, 591 A.2d at 171, which makes the conflict less than immediate.

88. In any matter in which a director possesses "a financial, business or other personal interest which does not devolve on the corporation or all stockholders generally," the director has the burden of establishing inherent fairness. Mills Acquisition Co. v. Macmillan, Inc., 559 A.2d 1261, 1280 (Del. 1988). But see infra note 121.

89. See Citron, 584 A.2d at 499.

90. See Smith v. Van Gorkom, 488 A.2d 858, 872 (Del. 1985) (requiring that directors inform themselves of reasonably available material information before making judgment).

91. See generally Deborah A. DeMott, Puzzles and Parables: Defining Good Faith in the MBO Context, 25 WAKE FOREST L. REV. 15 (1990).

92. See Citron, 584 A.2d at 499.

93. See infra text accompanying notes 133-34.

94. See Revlon, Inc. v. MacAndrews \& Forbes Holdings, Inc., 506 A.2d 173, 182-83 (Del. 1986); Katz v. Oak Indus., Inc., 508 A.2d 873, 879 (Del. Ch. 1986). 
convertible debentures, ${ }^{95}$ as well as the contractually defined rights and limits on preferred stock. ${ }^{96}$ Moreover, fiduciary duties to minority stockholders commence only after their stock in the subsidiary is distributed to them. If the parent announces an intention to spin off a wholly owned subsidiary, its fiduciary duties to the subsidiary's eventual minority stockholders begin at the date the stock is distributed, not at the date the parent announces the spin-off plan. ${ }^{97}$

3. The Content of Intrinsic Fairness. Assuming that the parent's fiduciary obligation requires it to satisfy a standard of intrinsic (or entire) fairness, what, concretely, does that fairness require? The answer, to some extent, depends on the jurisdiction and the type of transaction. In Weinberger $v . U O P$, Inc. ${ }^{98}$ the Delaware Supreme Court's leading opinion defining fairness in the context of merger transactions between subsidiaries and their parents, the court explained that "fairness" incorporates two separable aspects, fair dealing and fair price. Questions under the "fair dealing" heading include "when the transaction was timed, how it was initiated, structured, negotiated, disclosed to the directors, and how the approvals of the directors and the stockholders were obtained." "Fair price" concerns "the economic and financial considerations of the proposed merger, including all relevant factors: assets, market value, earnings, future prospects, and any other elements that affect the intrinsic or inherent value of a company's stock." 100 Weinberger also recognized that, although these dimensions of fairness are distinct, ultimately "the test for fairness is not a bifurcated one .... A All aspects of the issue must be examined as a whole since the question is one of entire fairness." 101 If the transaction is not vulnerable on the "fair dealing" front, Weinberger recognized that price is then the predominant consideration. ${ }^{102}$

Other jurisdictions impose additional requirements on controlling shareholders in connection with cash-out transactions, which eliminate the minority's equity investment interest in the subsidiary. In Coggins v. New England Patriots

95. See Simons v. Cogan, 549 A.2d 300, 304-05 (Del. 1988).

96. See Jedwab v. MGM Grand Hotels, Inc., 509 A.2d 584, 595 (Del. Ch. 1986).

97. See Anadarko Petroleum Corp. v. Panhandle E. Corp., 545 A.2d 1171 (Del. 1988) (parent did not owe fiduciary duty to prospective stockholders of subsidiary after parent declared intention to spin off subsidiary).

98. Weinberger v. UOP, Inc., 457 A.2d 701 (Del. 1983).

99. Id. at 711 .

100. Id.

101. Id.

102. After Weinberger, the plaintiff's "ordinary" monetary remedy is appraisal, see id. at 714 , unless the defendants have breached their duties of fair dealing. In a case involving a breach of duties of fair dealing, the chancery court may fashion an appropriate remedy, including rescissory damages. Id. An appraisal under the Delaware statute entitles the plaintiff to the "fair value" of his stock, exclusive of elements speculatively attributable to the merger. Id.; see also DEL. CODE ANN. tit. 8, § 262(h). Suppose that, in contrast, the plaintiff's bases for challenging the fairness of the price fail. Should the fair dealing claim survive? In the case In re Tri-Star Pictures, Inc., No. CIV. A.9477, 1992 WL 37304 (Del. Ch. Feb. 21, 1992), the court held that, although a showing of injury is unnecessary when the plaintiff seeks restitution, a showing of individual harm or damage is necessary when the plaintiff seeks compensatory monetary relief. 
Football Club, Inc. ${ }^{103}$ the Supreme Judicial Court of Massachusetts held that a controlling shareholder (who was also a director) who benefitted from such a transaction "must demonstrate how the legitimate goals of the corporation are furthered." Similarly, the New York Court of Appeals, in Alpert v. 28 Williams St. Corp. ${ }^{105}$ required the majority to demonstrate that a freeze-out merger advanced "a general corporate interest." The court stated that its concept of fiduciary obligation went beyond fair price and fair dealing to encompass a requirement that all shareholders be treated equally unless a bona fide business purpose would be better served by unequal treatment. ${ }^{106}$

In other types of transactions, an intrinsic fairness test examines whether the parent has benefitted at the expense of the subsidiary; if it has, the parent must establish that the transaction was "objectively fair."107 If the parent has entered into a contract with the subsidiary to buy goods the subsidiary produces, and the parent subsequently breaches the contract, the intrinsic fairness standard requires the parent to prove that the subsidiary could not possibly have met its own performance obligations under the contract. ${ }^{108}$ Intrinsic fairness requires a parent to disgorge the benefit it receives by wrongfully diverting business to itself from its subsidiary. ${ }^{109}$ If a parent files consolidated tax returns with a subsidiary, "intrinsic fairness" requires the parent to justify its share of the allocation; the parent may not gain at the subsidiary's cost. ${ }^{110}$ If both corporations contributed to a tax savings, the parent may not appropriate it entirely. ${ }^{11}$

103. 492 N.E.2d 1112 (Mass. 1986).

104. Id. at 1118 .

105. 473 N.E.2d 19 (N.Y. 1984).

106. Id. at 28.

107. Sinclair Oil Corp. v. Levien, 280 A.2d 717, 720 (Del. 1971). According to Sinclair Oil, the parent self deals--thereby triggering the intrinsic fairness test-when it "causes the subsidiary to act in such a way that the parent receives something from the subsidiary to the exclusion of, and detriment to, the minority stockholders of the subsidiary." Id. This test couples the parent's exercise of control with a benefit it alone receives, at the expense of the subsidiary's minority shareholders.

108. Id. at 723 (parent's breach of contract to purchase, through wholly owned subsidiary, minimum amounts of crude oil and refined oil products from subsidiary). Suppose the subsidiary's directors approve a proposed modification of the contract to conform the contract's express performance requirements to the parent's anticipated practice (based on its past practice). The modification may be evaluated from the perspective of commercial law norms as well as corporate law norms. Contemporary commercial law does not require that a modification be supported by separate consideration. If the contract involves goods, $\$ 2-209$ of the Uniform Commercial Code imposes simply a test of "good faith" to determine whether the modification is enforceable. The pertinent question is whether the proposal to modify was motivated by a "legitimate commercial reason." Legitimacy appears to be determined solely by the motives of the party benefitting from the modification. See U.C.C. \& 2-209, cmt. 2 (1990). Somewhat different questions are pertinent within the realm of corporate law. Should the decision to modify be treated as a simple business judgment? Should it be subject to the intrinsic fairness standard? Especially if the modification is unilaterally favorable to the parent, the parent seems to be benefitting to the exclusion of the minority shareholders in the subsidiary, which clearly triggers review under the intrinsic fairness standard.

109. See Warren v. Century Bankcorp., Inc., 741 P.2d 846, 852 (Okla. 1987) (ordering disgorgement when parent of bank corporation created wholly owned subsidiary to make loans to prior customers of bank).

110. See Case v. New York Cent. R.R., 204 N.E.2d 643, 647 (N.Y. 1965)

111. See Smith v. Tele-Communication, Inc., 184 Cal. Rptr. 571, 575 (Cal. Ct. App. 1982). 
Finally, if the parent controls the subsidiary's operational decisions and causes the subsidiary to enter into transactions with it, intrinsic fairness requires the parent to establish that it was not the cause of the subsidiary's lost profits. ${ }^{112}$ In Summa Corp. v. Trans World Airlines, Inc., the airline's controlling shareholder, Hughes Tool Co. ("Toolco"), at the behest of Toolco's sole shareholder, Howard Hughes, refused to allow the airline to purchase its own jets directly from airplane manufacturers. ${ }^{113}$ Instead, the airline leased or bought jets from Toolco on terms that were profitable to it as the seller. Mr. Hughes" "evasive nature and difficult temperament" led Toolco to delay ordering planes, which further delayed the airline's access to them. ${ }^{114}$ As a result, the airline failed to establish the jet fleet it needed to remain competitive. Under the intrinsic fairness standard, which Toolco failed to meet, the parent is liable for the subsidiary's losses unless it is able to establish other causes for them. ${ }^{115}$

4. Transactions Outside the Reach of Intrinsic Fairness. Not all relationships or transactions that somehow connect a parent corporation to its subsidiary are subject to the intrinsic fairness standard. In general, intrinsic fairness applies only when the parent benefits "at the expense" of its subsidiary. ${ }^{116}$ Not all transactions that link a benefit to the parent with a detriment to the subsidiary or its minority shareholders prove problematic. The parent's benefit is not "at the expense of" the subsidiary if it stems from the parent's own position or set of entitlements, gained under rules set by government agencies or other third parties, even if the outcome is not favorable to the subsidiary. ${ }^{117}$ Moreover, transactions that treat all shareholders in the subsidiary equally do not trigger the intrinsic fairness test. If the subsidiary declares a dividend on its one class of stock, paying the same amount per share, the intrinsic fairness test does not apply because the parent has not received a benefit unavailable to all shareholders. ${ }^{118}$

The decision to declare the dividend is simply a business judgment made by the subsidiary's directors, subject to the statutory financial tests that apply to all dividends. ${ }^{119}$ Analysis is more complicated if the subsidiary has more than one class of stock outstanding. If the parent owns one class of stock and minority shareholders in the subsidiary own the other, a decision to declare a dividend on

112. See Summa Corp. v. Trans World Airlines, Inc., 540 A.2d 403, 407 (Del. 1988).

113. Id.

114. Id. at 405 .

115. Id. at 407. Indeed, on the record in Summa Corp. it was beside the point how the court allocated the burden on this question of causation. The court concluded that substantial evidence established that TWA's delivery priority would have been competitive with other airlines had Mr. Hughes simply permitted Toolco to negotiate with a key airline manufacturer; thus, "for reasons clearly attributable to the eccentric or idiosyncratic business methods of Howard Hughes, TWA was unable to establish a jet fleet as quickly as its competitors." Id.

116. See Sinclair Oil, 280 A.2d at 720.

117. See Getty Oil Co. v. Skelly Oil Co., 267 A.2d 883 (Del. 1970).

118. Sinclair Oil, 280 A.2d at $720-21$.

119. Id. at 721 . 
the class owned by the parent is subject to the intrinsic fairness standard. ${ }^{120}$ But the parent may be able to satisfy this standard if, as in Burton $v$. Exxon Corp., its class is a preferred stock with cumulative dividend rights prior to those of the class held by the minority, if the dividends are in arrears, and if the subsidiary lacks the financial ability to satisfy the arrearages on the class of stock held by the parent. ${ }^{121}$

5. The Impact of Process. Recent Delaware cases involving parentsubsidiary mergers have considered the impact of process on the standard of judicial review applicable to claims against the parent corporation. If the subsidiary has unaffiliated directors who negotiate on its behalf with the parent, and if they negotiate with adversarial skill and vigor, should the business judgment standard then govern the court's review? Likewise, if the parent complies with its duty to be candid in sharing material information about the transaction with the subsidiary's minority shareholders, and a majority of the minority shareholders then vote in favor of the transaction, should subsequent judicial review proceed under the business judgment standard?

Current Delaware case law attaches less significance to the outcomes of shareholder voting than to credible efforts put forth by nonaffiliated directors. In Rosenblatt $v$. Getty Oil Co., ${ }^{122}$ a special committee of unaffiliated directors of the subsidiary negotiated a merger with the parent. The negotiations unquestionably had a strongly adversarial flavor. ${ }^{123}$ The Delaware Supreme Court held that the subsequent ratification of the transaction by the subsidiary's minority shareholders shifted to the plaintiffs the burden of proving that the

120. See Burton v. Exxon Corp., 583 F. Supp. 405, 415-16 (S.D.N.Y. 1984)

121. Id. at 419-20. An intriguing question is why the intrinsic fairness test does not apply each time directors authorize a transaction with a differential impact on different classes of stock, if the directors themselves own a large portion of the class advantaged by the transaction. To be sure, cases tend to assume that directors' ownership of common stock, in itself, does not create a disqualifying conflict as to transactions involving the common stock. See, e.g., Unocal Corp. v. Mesa Petroleum Co., 493 A.2d 946, 958 (Del. 1985). But suppose that, as in Eisenberg v. Chicago Milwaukee Corp., the directors own a substantial percentage of the common stock and vote to approve a tender offer for noncumulative preferred stock at an offer price equal to a little more than half of the preferred's redemption price. See Eisenberg v. Chicago Milwaukee Corp., 537 A.2d 1051 (Del. Ch. 1987). The corporation in Eisenberg was "abundant[ly] liquid," a condition attributable in part to its directors' decision not to pay dividends for 16 years. Id. at 1053-54. Indeed, the corporation, which once operated a railroad, had few assets other than $\$ 300$ million in cash and $\$ 90$ million in real estate. Each dollar paid to repurchase and cancel a share of preferred would become a dollar more for the common in an eventual liquidating distribution of assets. The Eisenberg court's opinion held that the disclosure that accompanied the tender offer was deficient because it misstated the purpose of the tender offer and omitted facts relevant to assessing the adequacy of the price. Id. at 1058. The opinion does not discuss the applicability of an entire fairness standard to the directors' decision to authorize the tender offer. But see note 199 infra. The opinion does conclude, however, that the offer was "inequitably coercive," because the directors disclosed they intended to seek delisting of the preferred from the New York Stock Exchange, a statement the court found misleading. Eisenberg, 537 A.2d at 1062.

122. 493 A.2d 929 (Del. 1985).

123. Id. at 935-36. Negotiations focused on reaching a mutually acceptable exchange ratio for the Getty stock to be received by the Skelly minority. Negotiations were complicated by the parties' differing valuation techniques for Skelly's assets. Getty anticipated an exchange ratio of .46 to .55 of one Getty share per Skelly share. The eventual ratio was .5875 . Id. at 935-36. 
transaction was unfair. ${ }^{124}$ Despite this shift in the ultimate burden of persuasion, the court applied the entire fairness standard to the transaction. ${ }^{125}$ In Citron v. E.I. DuPont de Nemours \& Co. ${ }^{126}$ the chancery court held that the fact that the terms of a merger with the parent corporation were negotiated on the parent corporation's behalf by the subsidiary's unaffiliated directors did not shift the standard of review away from entire fairness to business judgment. ${ }^{127}$ To be sure, although the standard remains entire fairness, the burden shifts to the plaintiff to establish a lack of fairness. ${ }^{128}$ Moreover, bargaining as if the parties had an arm's-length relationship is said to be "strong evidence that the transaction meets the test of fairness." 129

Why does entire fairness remain the applicable standard? As Citron acknowledges, in most transactions between a corporation and its fiduciaries, such as a sale of assets between a corporation and an individual director, if the transaction is approved in good faith by fully informed, disinterested directors or fully informed, disinterested stockholders, subsequent challenges to the transaction confront the business judgment rule. ${ }^{130}$ Judicial review is then limited to "issues of gift or waste with the burden of proof upon the party attacking the transaction." 131 Citron reasons that transactions with fiduciaries who also control the corporation should be subject to a different standard:

Parent subsidiary mergers, unlike [directors'] stock options, are proposed by a party that controls, and will continue to control, the corporation, whether or not the minority stockholders vote to approve or reject the transaction. The controlling stockholder relationship has the inherent potential to influence, however subtly, the vote of minority stockholders in a manner that is not likely to occur in a transaction with a noncontrolling party.

Even where no coercion is intended, shareholders voting ... might perceive that their disapproval could risk retaliation of some kind by the controlling stockholder. For example, the controlling stockholder might decide to stop dividend payments or to effect a subsequent cash out merger at a less favorable price, for which the remedy would be time consuming and costly litigation. At the very least, the potential for that perception, and its possible impact upon a shareholder vote, could never be fully eliminated. ${ }^{132}$

124. Id. at 937.

125. The transaction satisfied the standard. Id. Accord Bershad v. Curtiss-Wright Corp., 535 A.2d 840,846 (Del. 1987) (noting that defendants retain the burden of proving complete disclosure of material facts relevant to the shareholder vote).

126. 584 A.2d 490 (Del. Ch. 1990). Citron does not explicitly address the question whether the same logic applies to transactions other than mergers. Id. at 502. But cf. Palley v. McDonnell Co., 295 A.2d 762, 767 (Del. Ch. 1972), affd, 310 A.2d 635 (Del. 1973) (directors of subsidiary were not "allowed to negotiate freely for [subsidiary's] benefit with full knowledge of what the transaction was all about"; court concludes that entire fairness standard is applicable to transaction in which subsidiary sold cameras to parent).

127. Citron, 584 A.2d at 502 .

128. See Summa Corp. v. Trans World Airlines, Inc., 540 A.2d 403, 406-07 (Del. 1988) (holding that in the absence of arm's-length bargaining, burden of showing entire fairness remains on parent who benefits from transaction to exclusion of minority shareholders in subsidiary).

129. Weinberger v. UOP, Inc., 457 A.2d 701, 710 n.7 (Del. 1983).

130. Citron, 584 A.2d at 500-01.

131. Marciano v. Nakash, 535 A.2d 400, 405 n.3 (Del. 1987).

132. Citron, 584 A.2d at 502. 
Moreover, the parent's potential mode of retaliation against subsidiary directors is even more obvious than the scenario described in Citron. However independent they may be, a subsidiary's directors are subject to election and, unless the subsidiary has cumulative voting, the majority stockholder elects all directors. In fact, the majority stockholder may also be able to remove all directors without any showing of cause. ${ }^{133}$ A majority shareholder's decision to retaliate by removing or by not reelecting a director is not likely to be actionable at all.

Occasionally, however, a transaction eludes the grasp of entire fairness review. In Cinerama, Inc. v. Technicolor, Inc., ${ }^{134}$ the plaintiff challenged a merger transaction negotiated by Technicolor's directors to conclude a third party's two-step acquisition of all Technicolor shares. The Technicolor directors predated the third party's acquisition; only one director had a significant financial interest in the transaction not shared by all holders of Technicolor stock. The court held that

when a majority shareholder takes no action with respect to the negotiation for
the corporation or approval of a proposed transaction (and uses no corporate
information that would not be available to an arm's-length party), he has no duty
to the corporation or its shareholders with respect to that transaction apart from
such duties as are owed by any person in such circumstances.....

As a consequence, the applicable standard of review is the business judgment standard. ${ }^{136}$

Read as a whole, these cases exhibit considerable skepticism about the normative significance of mere ritual and form. That the subsidiary is represented in negotiations by directors who lack formal ties to the parent in itself does not establish that the directors adequately protected the minority's interests. In contrast, if the representatives of the subsidiary and the parent bargain as if they had an arm's-length relationship-a context-and-fact-dominated determination-that will be relevant to showing entire fairness. The parent's control over the subsidiary limits the significance of the minority's vote to approve the transaction; even if fully informed, the minority votes in a context inescapably shaped by the parent's control.

6. The Ineffable Result of Hypothetical Arm's-Length Bargaining. A separate reason for expansive judicial review is the practical difficulty, in many of these situations, of determining the result that truly independent parties would

133. See DEL. CODE ANN. tit. $8, \S 141(\mathrm{k})$ (1974) (permitting majority shareholder to remove any or all directors without showing cause unless corporation has cumulative voting or board is classified).

134. No. CIV.A.8358, 1991 WL 111134 (Del. Ch. June 24, 1991).

135. 1991 WL 111134 at *19. Such duties would include the duty not to practice fraud and the duty not to knowingly participate in a breach of directors' fiduciary duty. See id. at *19-20.

136. Cinerama's facts closely resemble negotiations with a third party, not a controlling shareholder, given the court's finding that Technicolor's new majority shareholder had no access to confidential information that would be atypical in a negotiated transaction. 
have achieved in arm's-length negotiation. ${ }^{137}$ The result may be ascertainable "within a narrow margin of error" if the transaction involves fungibles. ${ }^{138}$ Otherwise, at most, a standard of hypothetical arm's-length bargaining might be used "to set limits on either side outside of which one can say with some assurance that the parties would not have agreed at all ...."139 These limits, however, are not especially useful information if they are very far apart. In any event, if the arm's-length result is unknowable, shareholders lack a benchmark against which to analyze the data they are given. Moreover, parties negotiating in the shadow of an intrinsic fairness standard may behave differently. In particular, Delaware cases examine whether the subsidiary's directors had "real bargaining power" to strike an arm's-length-like deal with the parent, ${ }^{140}$ or whether the parent dictated the terms of the transaction or presented the subsidiary's directors with a non-negotiable offer and asked them to determine whether its terms were fair. ${ }^{141}$ Unless the subsidiary's directors were able to bargain freely, the burden of showing that the transaction was entirely fair remains with the parent. ${ }^{142}$

The past decade of leveraged buyout transactions generated many cases in Delaware challenging the conduct of directors who reviewed managementinitiated buyouts. Describing cases in which directors evaluated management buyout proposals, the present Chancellor wrote that Delaware courts are motivated by a concern that directors not indulge in a charade. They look for "the substance of an arm's-length process," for a good-faith, informed attempt to approximate arm's-length bargaining. ${ }^{143}$ Although these observations are limited to directors' roles in reviewing proposed management buyout transactions, they seem to apply more broadly as well. The Chancellor's concerns seem pertinent to situations in which directors review transactions involving controlling shareholders. As we have seen, however, in the absence of arm's-length bargaining on behalf of the subsidiary, the consequence is that the parent retains the burden of proving entire fairness. Is this risk much of a stimulus? The Chancellor's analysis acknowledges that committees of independent directors are

137. See Citron, 584 A.2d at 502. But see John A. C. Hetherington, Defining the Scope of Controlling Shareholders' Fiduciary Responsibilities, 13 CANADA-U.S. L.J. 103 (1988) (advocating recognition that fiduciary constraint is contractually based and should be interpreted to enhance overall shareholder wealth).

138. See Ewen v. Peoria \& E. Ry. Co., 78 F. Supp. 312, 317 (S.D.N.Y. 1948).

139. Id.

140. See Rabkin v. Olin Corp., [1990 Transfer Binder] Fed. Sec. L. Rep. (CCH) I 95,255, at 96,164 (Del. Ch. Apr. 17, 1990).

141. Id. (defendant retains burden of establishing entire fairness).

142. This contemporary approach is supported by Pepper v. Litton, 308 U.S. 295, 306-07 (1939), in which Justice Douglas observed that the essence of the test which equity applies to a fiduciary's dealings with a corporation is "whether or not under all the circumstances the transaction carries the earmarks of an arm's-length bargain." The earmarks of a process resembling arm's-length bargaining may be evident even when the result of a hypothetical arm's-length bargain is not. Equity's interest in examining all the circumstances, emphasized in Pepper v. Litton, corresponds to the contemporary inquiry into the reality of the bargaining power formally possessed by the subsidiary's directors.

143. See William T. Allen, Independent Directors in MBO Transactions: Are They Fact or Fantasy?, 45 BUS. LAW. 2055, 2062 (1990). 
impelled to do what they must, out of a "sense of duty," which he urges committee advisors to instill in committee members. ${ }^{144}$

The adviser's role goes beyond providing technically adept advice to encompass a program of moral education directed toward the adviser's client. The program itself, of course, is shaped by the rhetoric of fiduciary doctrine; it translates the rhetoric into operational consequences. An additional stimulus-beyond the risk that the parent will bear the burden of proving entire fairness-is the risk of personal liability to the unaffiliated directors themselves. If they undertake but fail in a distinct mission on behalf of the minority shareholders, the unaffiliated directors may be individually liable to minority shareholders for their provable losses. ${ }^{145}$ However, two factors undermine the efficacy of this stimulus. First, the Delaware corporation statute permits a corporation's certificate of incorporation to include an exculpatory provision eliminating directors' liability to the corporation or its stockholders for money damages arising from the directors' breach of a duty of care. ${ }^{146}$ Second, liability and litigation expenses generated by such claims may be covered by directors' and officers' liability insurance. ${ }^{147}$

\section{B. Fiduciary Constraints and the KeepRite Litigation}

Litigation challenging the KeepRite transaction would proceed very differently in the United States under the fiduciary doctrine. The litigation would, in some respects, be more complicated, and could involve a set of corollary questions. The form of the litigation would be different. Unless the subsidiary sued its parent, alleging breach of fiduciary obligation, a shareholder would challenge the asset acquisition in a derivative suit. The court would characterize the alleged wrong as an injury to the subsidiary corporation. Consequently, an aggrieved shareholder would not be able to bring a direct action on her own behalf against the parent. Although many Canadian corporation statutes contain provisions that permit a shareholder, if so authorized by the court, to bring a derivative action on behalf of a corporation, ${ }^{148}$ the plaintiff may pursue the same claim through an oppression action. Given the relative procedural simplicity of oppression actions, ${ }^{149}$ they have eclipsed derivative suits in Canada except when the defendants are unaffiliated third parties who have injured the corporation. ${ }^{150}$

144. Id. at 2061.

145. See Schneider v. Lazard Freres \& Co., 552 N.Y.S.2d 571 (App. Div. 1990); In re RJR Nabisco, Inc. Shareholders Litig., [1988-1989 Transfer Binder] Fed. Sec. L. Rep. (CCH) I 94,194 (Del. Ch. Jan. 31,1989 ).

146. See Del. Code ANN. tit. 8, \& 102(b)(7) (1974).

147. See generally JOSEPH W. BISHOP, LAW OF CORPORATE OFFICERS AND DIRECTORS (Supp. 1989).

148. See CBCA §§ 239-40; OBCA §§ 245-46.

149. See DENNIS PETERSON, SHAREHOLDER REMEdies IN CANADA $\S 18.229$ (1991). In particular, Canadian statutes permit an oppression remedy to be sought summarily through an application.

150. See id. \$18.237. 
Substantively, the litigation in the United States would also differ. Applicable legal doctrine would identify who (or what) owed duties to whom and, on facts like those in KeepRite, the general content of those duties. As a result, expectations for the conduct of a committee of independent directors could be articulated with greater clarity. The standard applicable to the merits of the transaction and to the conduct of the parent corporation would likely be the "intrinsic fairness" standard. Depending on the circumstances, either the plaintiff or the defendant might bear the onus of establishing that the transaction was (or was not) fair.

1. The Form of the Litigation. A shareholder challenge to the KeepRite transaction most likely would be litigated as a derivative suit because any injury initially affected the subsidiary corporation itself. Minority shareholders suffered only secondarily, as a result of the subsidiary's alleged overpayment for the assets it purchased. Relatedly, if the parent benefitted from the transaction, beyond its receipt of the purchase proceeds, and is under a duty to account for the amount of its benefit, the right to the accounting again seems, in the first instance, to run in favor of the subsidiary corporation. In the United States, shareholders have been able to raise such claims as plaintiffs in direct actions only in some jurisdictions, ${ }^{151}$ and also only in closely held corporations. ${ }^{152}$ In contrast, Canadian courts have generally permitted the statutory oppression provisions to be used as vehicles for claims that otherwise would be pursued as derivative actions. ${ }^{153}$

The derivative action may be uniquely complicated as a type of private civil litigation. Complexity aside, three major consequences follow from mandating that the plaintiff's challenge proceed as a derivative suit. First, if the plaintiff is successful in recovering money damages, the judgment presumptively will be payable to the subsidiary corporation, ${ }^{154}$ which will benefit the subsidiary's creditors. ${ }^{155}$ Second, derivative litigation is subject to an unusually high degree of judicial control. In particular, the court must approve any settlement or voluntary dismissal of the suit. ${ }^{156}$ Third, the corporation itself, through its directors, may be able to assume control over the claim asserted. Most jurisdictions in the United States require the prospective plaintiff either to demand that the corporation's directors take action or to allege facts which demonstrate to the

151. See, e.g., Bagdon v. Bridgestone/Firestone, Inc., 916 F.2d 379, 384 (7th Cir. 1990) (applying Delaware law mandating use of derivative action).

152. See, e.g., Donahue v. Rodd Electrotype Co. of New England, Inc., 328 N.E.2d 505 (Mass. 1975); Crosby v. Beam, 548 N.E.2d 217 (Ohio 1989).

153. See, e.g., Westfair Foods Ltd. v. Watt, [1991] 4 W.W.R. 695 (Alta. Ct. App. 1991) (directors unfairly disregarded interests of preferred shareholders by, inter alia, failing to create a committee independent of controlling shareholders to consider proposed dividend policy); see generally Jeffrey G. MacIntosh, The Oppression Remedy: Personal or Derivative, 70 CAN. BAR REV. 29, 52 (1991).

154. See generally DEBORAH A. DEMOTT, SHAREHOLDER DERIVATIVE ACTIONS $\$ 7: 06$ (1987 \& Supp. 1991).

155. See Glenn v. Hoteltron Sys., Inc., 547 N.E.2d 71, 74 (N.Y. 1989).

156. See, e.g., FED. R. CIV. P. 23.1. 
court that making a demand would have been futile; the remainder mandate demand universally even when the circumstances demonstrate futility. ${ }^{157}$

Recent Delaware cases place the burden on the plaintiff to allege facts that, if true, suffice to excuse demand. The test is whether the facts alleged in the complaint, if true, create a reasonable doubt, either that a majority of the directors who approved the transaction were not disinterested and independent, or that the transaction was otherwise not the product of valid business judgment. ${ }^{158}$ The latter basis for excuse would encompass a claim that the terms of the transaction constituted waste because the corporation received grossly inadequate consideration. ${ }^{159}$ In the demand context, directors are not disinterested if they have a personal economic interest in the transaction. ${ }^{160}$ Directors, however, do not necessarily lack independence simply because the corporation has a majority shareholder. The allegation of control must be coupled with "such facts as would demonstrate that through personal or other relationships the directors are beholden to the controlling person."161 The "beholden to" standard could be met by a variety of allegations, including, for example, employment relationships between the subsidiary's directors and the subsidiary or the parent corporation. ${ }^{162}$ If the plaintiff does make a demand and the board refuses it, the court's review is limited to whether the board's investigation was reasonable and in good faith. ${ }^{163}$

2. Fiduciary Standards and Expectations. The relationships and transactions in KeepRite are readily amenable to analysis under fiduciary doctrine. Indeed, the parent-subsidiary pattern in KeepRite so readily lends itself to analysis that, prior to any transaction between KeepRite and its parent, ICG, or between

157. See, e.g., RMBCA § 7.42; FLA. STAT ANN. § 607.0704(1) (West 1993); GA. CODE ANN. § 14-2742 (1989).

158. See Aronson v. Lewis, 473 A.2d 805, 814 (Del. 1984). Delaware cases also hold that if the plaintiff makes a demand, she thereby creates a conclusive presumption that the board has sufficient independence to respond to the demand. See Spiegel v. Buntrock, 571 A.2d 767, 777 (Del. 1990); Thorpe v. CERBCO, Inc., 611 A.2d 5 (Del. Ch. 1991).

159. See, e.g., Avacus Partners, L.P. v. Brian, [1991 Transfer Binder] Fed. Sec. L. Rep. (CCH) II 96,232 , at 91,215 (Del. Ch. Oct. 24, 1990) (allegation that corporation exchanged stock worth $\$ 16$ million to gain control of company whose primary assets were purchased for $\$ 110,000$ during previous year, and allegation that corporation exchanged stock worth $\$ 5$ million for shares and notes with market value of about $\$ 400,000$, are both litigable claims of waste).

160. See, e.g., Aronson, 473 A.2d at 815; Siegman v. Tri-Star Pictures, Inc., No. CIV.A.2666, 1989 WL 48746 (Del. Ch. May 30, 1989) (Tri-Star directors who were substantial shareholders in Coca-Cola Corporation, which sold entertainment assets to Tri-Star, were not disinterested because they would receive a pro rata share of the dividend Coca-Cola would pay as part of the transaction, a financial interest not shared by other Tri-Star shareholders.).

161. See Aronson, 473 A.2d at 815 .

162. See Sealy Mattress Co. of New Jersey, Inc. v. Sealy, Inc., [1987 Transfer Binder] Fed. Sec. L. Rep. (CCH) I 93,331 (Del. Ch. July 20, 1987).

163. See Thorpe v. CERBCO, 611 A.2d 5, 11 (Del. Ch. 1991). Suppose a majority of the board is interested in the transaction and appoints a committee of disinterested directors to investigate the claim. If the full board itself refuses the demand (contrary to the committee's recommendation), the plaintiff's complaint setting forth these allegations has raised a reasonable doubt about the board's good faith. See id. 
KeepRite and the wholly owned subsidiaries, ICG's duties to KeepRite could be outlined explicitly. Likewise, expectations could be clearly articulated for KeepRite's unaffiliated directors, if they act on its behalf, in connection with the transaction.

If ICG is a fiduciary of KeepRite's minority shareholders, its dealings with the subsidiary will be tested against a standard of "intrinsic fairness" if it selfdeals by obtaining benefits not proportionately derived by KeepRite's minority shareholders. This criterion for self-dealing is met by ICG's sale of assets to KeepRite through its wholly owned subsidiaries. Like Toolco in Summa Corp., the selling shareholder has an opportunity, not available to all subsidiary shareholders, to dispose of assets to a particular purchaser.

To be sure, the content of entire fairness, as applied in particular to the price paid for assets, resists abstract articulation. A substantive standard of hypothetical arm's-length bargaining may be useful if the assets being purchased or sold are fungibles; otherwise, the standard will, at best, help to set outside limits against which to measure the actual terms of the transaction. In contrast, the consequences may be much less ineffable if unaffiliated directors of the subsidiary are advised to act as if they were negotiating an arm's-length transaction. Moreover, any hope the controlling shareholder may harbor of eluding the "entire fairness" standard-based on the recent Technicolor opinion ${ }^{164}$-depends heavily on whether the subsidiary's interests are represented by directors who are visibly uncompromised by ties to the parent as well as whether the parent has enjoyed, as controlling shareholder, privileged access to nonpublic information generated by the subsidiary.

3. Burdens in the Litigation. Current Delaware cases engage in complex sequences of burden-shifting in litigation challenging transactions between parents and their subsidiaries. As a conflicted fiduciary, the parent that selfdeals clearly bears, as an initial matter, the burden of showing intrinsic fairness, a concept that, to some extent, may be divided between components of fair dealing and fair price. If a majority of the subsidiary's minority shareholders approve the transaction, after receiving candid disclosure from the parent, the burden shifts to the party challenging the fairness of the transaction. Similarly, the burden shifts if the terms of the transaction were negotiated on the subsidiary's behalf by unaffiliated directors who acted as if they were negotiating within an arm's-length relationship. The appellate opinion in KeepRite is not as clear as one might wish about factual underpinnings that become crucial for resolving these questions in a framework shaped by fiduciary doctrine. In particular, the opinion is silent about the committee's accomplishments on behalf of the subsidiary. Fiduciary analysis makes it important to clarify the committee's mandate in advance of its work. At a minimum, in the absence of

164. See supra text accompanying notes 129-30. 
such clarity, the risk is higher that the burden of showing substantive fairness will remain with the parent corporation.

Indeed, some recent Delaware cases involving parent-subsidiary transactions expressly note the parent's exquisite awareness throughout the transaction that litigation eventually would ensue. As a result, the parent tried to minimize its subsequent vulnerability in litigation, where it knew the court would apply the entire fairness standard in reviewing the transaction and the process that led to it. In Citron, for example, the parent-after deciding to acquire the minority interest in its subsidiary-did not formulate the merger terms itself. ${ }^{165}$ Instead, it retained an investment banking firm to recommend terms. The parent placed no constraints on the valuation approaches the investment bank might take or on the merger terms it might ultimately recommend. The parent also gave the minority veto power by making the merger expressly subject to approval by a majority of the minority shareholders. ${ }^{166}$

4. Canada's Regulatory Alternative. Relationships like those in KeepRite occur with frequency in Canada because corporate ownership is so highly concentrated. As the KeepRite opinions illustrate, case-by-case litigation under the general statutory prohibition on oppression is not likely to generate a body of case law prescribing and applying crisply defined articulations of duty. Private litigation-like the KeepRite case and the Delaware cases-does not occur in an institutional vacuum, however. In particular, both Canada and the United States have elaborate sets of regulations that affect transactions in securities. Large differences in securities regulation between the two countries partially account for the even larger differences in norms applicable to private corporate litigation.

The Ontario Securities Commission ("OSC"), Canada's most prominent securities regulator, recently promulgated an elaborate and comprehensive set of rules termed a "Policy Statement" to govern "related party transactions" involving issuers of securities subject to regulation by the OSC. ${ }^{167}$ The policy imposes disclosure, valuation, and approval requirements on enumerated types of transactions among related parties. These transactions include dispositions of assets, bids for securities by the issuer or its insiders, and "going private" transactions. The policy defines "related party" broadly to encompass, among others, persons or companies (other than lenders) that hold securities or contractual rights "sufficient to affect materially the control of an issuer of securities." 168 This definition includes, among the many relationships, the prototypical relationship between a parent corporation and its subsidiary.

165. Citron v. E.I. Du Pont de Nemours \& Co., 584 A.2d 490, 493 (Del. Ch. 1990) (noting parent's knowledge that "litigation challenging the acquisition was highly likely").

166. Id.

167. Ontario Securities Commission, Policy Statement 9.1-Disclosure, Valuation, Review and Approval Requirements and Recommendations for Insider Bids, Issuer Bids, Going Private Transactions and Related Party Transactions (July 5, 1991) [hereinafter Policy Statement 9.1].

168. Id. \& 2.2(14)(ii). 
If a related party transaction involves an asset with a value in excess of twenty-five percent of the issuer's market capitalization, the policy statement requires that an independent valuer prepare a formal valuation, to be filed with the OSC and summarized in proxy materials furnished to security holders. ${ }^{169}$ The policy statement regulates the scope and coverage of the valuation report and does not permit the use of a "conclusory statement of opinion as to the value or range of values." 170 Transactions of the same magnitude are also subjected to a minority approval requirement; ${ }^{171}$ they must be approved by holders of each class of affected security. The policy statement recommends as "good practice" the use of a special committee of independent directors to negotiate the terms of a transaction involving a related party; if such a committee does not carry out negotiations, a committee alternatively might review or report upon the transaction. ${ }^{172}$ The OSC's policy statement is structured so that parties who contemplate engaging in such a transaction must either comply with the statement or demonstrate to the OSC that "the grant of discretionary relief [from compliance] would not be prejudicial to the public interest . . .."173

The breadth of the policy statement's requirements suggests intriguing contrasts with the limits on the scope of federal securities regulation in the United States. Several of the policy statement's requirements would not be legally feasible if adopted in the United States by the federal Securities and Exchange Commission ("SEC"). In particular, the SEC probably lacks rulemaking authority under present statutes to mandate minority-approval voting requirements. ${ }^{174}$ Indeed, the SEC rule regulating "going private" transactions

169. Id. $\S 18.1$. Having the asset valued does not mean that the corporation's shareholders become entitled to receive a prorated pay-out to them on demand. Rights to dissent are defined by the relevant corporate law. See supra note 24.

170. Policy Statement 9.1 , supra note 167 , at $\S 24.5(3)$.

171. Id. $\$ 20.1$. The minority approval requirement is subject to exceptions. The exceptions include transactions in which all holders participate pro rata (such as a rights offering or a bona fide dividend paid in cash or kind) and transactions involving sales of assets to wholly owned subsidiaries. Also exempt are negotiated transactions with a related party when the corporation has another shareholder holding more voting rights who supports the transaction and who is treated by the transaction equally on a pro rata basis with minority shareholders. Id. $\S \S 18.1,20.2(1)$. The minority approval requirement, additionally, is inapplicable if the related person already is the holder of $90 \%$ or more of each class of the issuer's securities and either a statutory appraisal remedy is available to minority security holders or "a substantially equivalent enforceable right is made available to the minority security holders." Id. § 20.2(2).

172. Id. $\$ \S 19.1,27.1$. The Commission recommends, but does not require, that the selection of the valuer, and instruction to the valuer, be made, "where possible," by a special committee of directors. Id. $\S 23.1$. In the small cast of interconnected players in Canadian corporate transactions, one might wonder about the efficacy of independent valuers and independent directors. Valuers wish for repeat business, which may bias their work, while independent directors come from "the relatively small pool of directorial talent in Canada [where] it will often be difficult to find directors who are not connected either by business or social links to important players in the corporate group." See Daniels \& MacIntosh, supra note 4 , at 927 . If they lack present links to key players, directors' behavior might be affected by the wish to have such ties in the future.

173. Policy Statement 9.1, supra note 167, \$\$ 3.2-3.4.

174. See The Business Roundtable v. SEC, 905 F.2d 406, 411 (D.C. Cir. 1990) (invalidating SEC rule mandating one-share-one-vote rule with court observing that Congress in Securities Exchange Act did not authorize SEC to promulgate rules that move "beyond control of voting procedures and into the 
does not mandate providing shareholders with either an independent valuation or an independent "fairness opinion" stating the writer's conclusory opinion as to fairness. ${ }^{175}$

The contrast between the United States and Canada is multi-dimensional. In the United States, the regulation of transactions between parents and their subsidiaries has evolved through two channels. First, it has developed through judicial elaboration of fiduciary norms in cases contesting particular transactions. Second, it has evolved as a result of the efforts of parties in subsequent transactions to conform their conduct to those articulated norms in order to minimize their potential vulnerability in litigation. The Canadian approach, in contrast, derives less specific guidance from the results of private litigation and much more from administrative directives. Given the detail of the OSC's policy statement, the Canadian approach leaves less discretion in the hands of private parties and their legal advisors. Ultimate resort, under the policy, is to the discretion of a securities administrator not the judgment of a court. In contrast, the United States leaves more choices open to private parties, inevitably placing more weight on the integrity of private legal and financial advisers. Not surprisingly, the U.S. approach has also created a highly complicated body of decisional law.

Coupled with greater flexibility in the United States is the hortatory impact of fiduciary language. Couching these issues in terms of fiduciary language is likely to have concrete consequences. Indeed, the OSC's policy statement (like the appellate opinion in KeepRite) says little about the optimal role for independent directors acting on behalf of the subsidiary. May these directors, consistent with their mission, simply react to a proposal from the parent? May they understand, at the outset, that they cannot refuse to proceed with the transaction? Must they play an active role in negotiating the terms of the transaction? Must they explore alternatives to a proposed transaction? In contrast, the Delaware materials examine these questions fully, in terms that expressly articulate aspirations for directors. Moreover, by expressly recognizing nonshareholder interests and equating them with shareholder interests, the Canadian oppression statutes themselves tend to defeat clarity in the articulation of directors' duties. Clarity is further thwarted by the statutes' explicit embracing of conflicting interests.

\section{IV}

\section{INTERESTS AND GRIEVANCES OF OTHER CORPORATE CONSTITUENTS}

Minority shareholders are not unique in their capacity to be injured by the acts of a corporation or the persons in control of it. Other parties who might be

distribution of voting power").

175. See Schedule 13E-3, 17 C.F.R. \& 240.13e-100, items 9(a), 9(b) (1991) (mandating disclosure to shareholders of any report, appraisal or opinion other than from counsel that is materially related to Rule 13e-3 transaction). Item 8 in Schedule 13E-3 requires that the issuer itself state its belief as to the fairness or unfairness of the transaction and state its basis for that belief. 
harmed include the corporation's bondholders, bank lenders, trade creditors, employees, a variety of government entities, and the communities in which the corporation either engages in business operations or ceases to do so. An important question that Canadian and American authorities answer differently is the extent to which these nonshareholder grievances should be resolved through litigation that applies norms defined by corporate law or fiduciary obligation. Canadian oppression provisions afford a statutory basis, grounded within corporation law, for the litigation of claims that, in the United States, are largely treated as matters for private contract. Indeed, Canadian oppression statutes permit ex post judicial responses to situations in which enforceable claims would otherwise be shaped exclusively by ex ante agreement among the parties.

\section{A. The Ambit of Contract and Its Limits}

Numerous U.S. cases support the general proposition that, subject to a few exceptions, only holders of equity securities may assert claims grounded in breach of fiduciary obligation against a corporation's directors or its controlling shareholder. Other constituents are limited to rights against the corporation defined by statute or by private contract. Even holders of preferred stock are limited to contractual rights and remedies insofar as the dispute concerns the preferred stock's defined rights that distinguish it from common stock. In the absence of a statutory or contractual inhibition, the corporation is free to take action that may disappoint the known or predictable expectations of its nonshareholder constituents. This freedom is limited by the implied contractual covenant of good faith and fair dealing, which disfavors overly literal interpretations of express language. Courts, in general, have not construed implied contractual obligations expansively, reflecting an unwillingness to compensate disappointed constituents when their expectations are not reflected in an express term of an explicit agreement with the corporation. ${ }^{176}$

Litigation involving leveraged buyouts ("LBOs") from the late 1980s illustrates the scope within which contract law norms define parties' legally

176. But cf. Sharon Steel Corp. v. Chase Manhattan Bank, N.A., 691 F.2d 1039, 1051 (2d Cir. 1982) (interpreting successor obligor clause in indenture so as to protect inferred interests of lender as well as interest of borrower). Sometimes procedural ingenuity has yielded results that substantive doctrine denied. Consider the history of the "conditional" or "anticipatory" Mareva injunction in English courts. A Mareva injunction, similar to a temporary restraining order under FED. R. CrV. P. 65(b), is designed to prevent a defendant from dissipating or hiding assets at the outset of litigation and thereby defeating or complicating the enforcement of a final judgment. See Mareva Compania Naviera S.A. v. Int'l Bulkcarriers SA "the Mareva," [1980] 1 All E.R. 213. An anticipatory Mareva order secured the defendant's assets prior to the time when the plaintiff had a vested and accrued cause of action. In contract litigation, an anticipatory Mareva order could precede the defendant's breach of contract. It would effectively enable the plaintiff to impose limits on the defendant's otherwise permissible use of its assets, prior to any breach of contract by the defendant and beyond any express contract terms comparably restricting the defendant's discretion. In any event, the era of the anticipatory Mareva order ended in 1991, when the Court of Appeal held that no injunction could be granted without a cause of action. See Veracruz Transp. Inc. (Liberia) v. VC Shipping Co., Inc., [1992] 1 Lloyd's Rep. 353. 
enforceable expectations. In Metropolitan Life Insurance Co. v. RJR Nabisco, Inc., ${ }^{177}$ the plaintiffs were institutional holders of long-term debt securities issued over a period of several years. The bondholders sued after RJR Nabisco's board facilitated an LBO for the corporation, a transaction that required the issuance of enormous amounts of additional debt. The price at which the bonds traded in the secondary markets and the bonds' ratings dropped drastically - but predictably-after the issuer announced plans for the LBO. The court held that by incurring debt to fund the LBO, the issuer and its directors did not breach any fiduciary obligation to the bondholders or any implied contractual obligation of good faith. Nothing in the indentures specifically or impliedly limited the issuance of additional debt. ${ }^{178}$

In response to the perceived risk of large, highly leveraged transactions, some underwriters and institutional bondholders demanded that indentures include provisions mandating, among other things, redemption of debt securities upon the occurrence of events like leveraged buyouts. Such provisions assure purchasers of debt securities that they will be able to sell the securities to the issuer, at a previously agreed-upon price, upon the occurrence of a specific, defined event that is likely to depress the secondary market price at which the securities would trade. ${ }^{179}$ A second type of risk-reduction provision entitles the bondholder to have the issuer adjust the interest rate. Practitioners recognize, however, that no such provision will define triggering events so comprehensively that perfect protection will result. ${ }^{180}$

Not surprisingly, some behavior oversteps the ambit of contractual norms. Behavior that is tortious is outside contract law's ambit. ${ }^{181}$ In Metropolitan Life, for example, the court permitted the plaintiffs to replead their fraud claims against RJR Nabisco. ${ }^{182}$ The plaintiffs alleged that officers of RJR Nabisco, to induce them to invest, made statements that were false in light of the officers' contemporaneous knowledge of plans for an LBO.

Additionally, if the corporation becomes insolvent, its financial condition dramatically relocates the focus of fiduciary analysis. Upon insolvency, the corporation's directors must act on behalf of its creditors, not its equity investors, at least when their interests conflict. ${ }^{183}$ In Credit Lyonnais Bank Nederland v.

177. 716 F. Supp. 1504 (S.D.N.Y. 1989).

178. Id. at 1508 .

179. See William W. Bratton, Jr., Corporate Debt Relationships: Legal Theory in a Time of Restructuring, 1989 DUKE L.J. 92, 156-57 n.282 (describing types of poison puts).

180. See Richard Brook, Debt Covenants and Event Risk: The Practitioner as a Source of Evidence 26-27 (Oct. 1990) (unpubilished manuscript on file with Law and Contemporary Problems). Brook's survey of practitioners also revealed that, even following the RJR-Nabisco transaction, large corporations continued to be able to issue bonds without some sort of event risk protection. Id. at 30 .

181. Contract norms become relevant if the person to whom a duty is owed effectively waives the tortious breach.

182. RJR Nabisco, Inc., 716 F. Supp. at $1522,1525$.

183. See Geyer v. Ingersoll Publications Co., No. CIV.A.12406, 1992 WL 136473 (Del. Ch. June 18, 1992). Early support stems from Justice Story's opinion in Wood v. Dummer, 30 F. Cas. 435 (D. Me. 1824), which characterizes a bank's capital stock as a trust fund to be maintained for the benefit of its creditors. The bank in Wood declared and distributed a dividend to shareholders, leaving it with 
Pathem Communications, Inc. ${ }^{184}$ Delaware's chancery court recently held that, prior to the point of actual insolvency, however defined, "in the vicinity of insolvency, a board of directors is not merely the agent of the residue risk bearers, but owes its duty to the corporate enterprise."185 The "enterprise," in turn, includes both creditors' and shareholders' interests.

Of course, this shift in directors' duties raises many questions. Do creditors have standing to sue if directors authorize a transaction that is imprudent from the creditors' standpoint? ${ }^{186}$ Should creditors be relegated to the remedies created by fraudulent conveyance law, which only permit them to recover assets that the corporation transferred without fair consideration if it thereby became insolvent? Perhaps Credit Lyonnais simply increases the probability that directors' decisions will be characterized as business judgments, thereby protecting decisions that might otherwise be vulnerable to shareholder challenge as evidencing undue favoritism toward creditors and undue risk-aversion at the creditors' behest. One might also reflect on transactions that increase the risk of insolvency. Are directors vulnerable if they make a decision-such as authorizing an LBO - that moves the corporation near but not into insolvency by greatly increasing the enterprise's overall degree of financial risk (and financial return as well)?

Within the corporation's set of financial creditors, interests are not identical. How would a court evaluate the disparate interests of different types of creditors? How are the interests of senior creditors to be weighed versus those of holders of junior subordinated debt? Financial creditors, moreover, have interests that are different from those of other creditors. Also, employees may favor directors' decisions that keep the enterprise operating, while secured lenders may favor the liquidation of operating assets sooner rather than later. In this light, it is significant that the state statutes that expressly authorize directors to take nonshareholder interests into account do not, with one arguable

insufficient assets to pay creditors' claims as they came due. Justice Story observed that shareholders' "rights are not to the capital stock but to the residuum after all demands on it are paid. On a dissolution of the corporation, the bill-holders and the stockholders each have equitable claims, but those of the billholders possess, as I conceive, a prior exclusive equity." Id. at 436-47.

Other jurisdictions treat differently the situation of directors once a corporation becomes insolvent. In Australia (the most extreme example), directors are personally liable for the corporation's business debts that are incurred when there are reasonable grounds to believe the corporation will not be able to pay all its debts when and as they come due. CoRPORATIONS LAW $\$ 592$ (1992) (Austl.). Moreover, directors who permit "trading whilst insolvent" commit a criminal offense. One consequence would be ineligibility, for five years following conviction, to manage a corporation without the court's permission. Id. \$229(3). In England, "trading whilst insolvent" is not criminalized, and directors are personally liable only if they knew or ought to have known that there was "no reasonable prospect the company would avoid going into insolvent liquidation ...." Insolvency Act 1986, \& 214(2)(a) (Eng.).

184. No. CIV.A.12150, 1991 WL 277613 (Del. Ch. Dec. 30, 1991).

185. Id. at $* 34$.

186. If directors are viewed as agents acting on behalf of the corporation's shareholders, imposing an additional extracontractual duty of directors to creditors creates duties to parties with systematically adversarial interests. In particular, treating directors as fiduciaries toward both vitiates any meaningful loyalty to the interests of either group. See Victor Brudney, Corporate Bondholders and Debtor Opportunism: In Bad Times and Good, 105 HARV. L. REV. 1821, 1838-40 (1992). 
exception, create any claim that a nonshareholder constituent could enforce by suit. $^{187}$ For the most part, these statutes operate simply to enlarge the scope of directors' discretionary decisionmaking. Additionally, the statutes do not establish any priority among the interests of nonshareholder constituents.

\section{B. The Ambit of Oppression Claims}

Canadian oppression statutes clearly reflect different assumptions about the primacy of shareholder interests, and about the significance of prior contractual definition for other constituents' interests and expectations. Oppression jurisprudence, in general, leads to fewer and duller lines of demarcation than does analysis using contractual or fiduciary norms. Contrasts between outcomes in recent cases in Canada and the United States help support these general assertions.

The boom in high-stakes acquisition activity in the 1980s did not bypass Canada. Oppression litigation followed inexorably in its wake. In Palmer $v$. Carling O'Keefe Breweries of Canada Ltd. ${ }^{188}$ the plaintiffs held shares in two series of preferred stock issued by a Canadian brewer. The instrument creating the rights of the preferred stock obliged Carling to redeem it at par value in the event of "liquidation, dissolution or the winding up of the company or any other distribution of assets of the company among its shareholders for the purpose of winding up its affairs." "I89 any of these events occurred as a result of voluntary action by Carling, the preferred stock was entitled to par value plus a premium. ${ }^{190}$

In 1987, I.X.L., a wholly owned subsidiary of Elders, a large Australian brewer, acquired all the common shares of Carling through a takeover bid and a subsequent compulsory acquisition of holdout shareholders. ${ }^{191}$ Elders subsequently decided to "marry" Carling's assets with the acquisition debt, which required the elimination of the preferred stock. Elders wished to achieve this end without redeeming the preferred shares, which were trading at prices much lower than their redemption price. The preferred shareholders failed to vote by a sufficient majority to amend the redemption price. Thereafter, Carling's directors voted to amalgamate Carling with a wholly owned subsidiary of I.X.L.,

187. See Charles Hansen, Other Constituency Statutes: A Search for Perspective, 46 BUS. LAW. 1355, 1372 (1991) (noting that only Connecticut statute provides that directors must take interests of nonshareholder constituents into account, author concludes that how directors take them into account is a discretionary business judgment).

188. 67 O.R.2d 161 (1989).

189. Id. at 162 .

190. Id.

191. Id. at 163 . The statutorily defined right of compulsory acquisition under the Ontario corporation statute is available to bidders who acquire $90 \%$ or more of the securities in a class pursuant to a takeover bid. See OBCA, R.S.O. ch, $4 \$ \S 186-87$. Once $90 \%$ or more of a class of equity securities has been acquired, the remaining shareholders may compel acquisition by the acquiring person. Id. $\S$ 188. 
a transaction that did not require any vote from the preferred shareholders. ${ }^{12}$ The amalgamated company thus owned Carling's income-producing assets and became subject to the acquisition debt. Elders-warned of the likelihood of an oppression claim by the preferred shareholders-entered into a set of agreements known collectively as the "support agreement." Elders agreed to indemnify the acquisition lenders, who agreed to waive any right of recourse against Carling. Elders also agreed to buy the preferred shares at their stated redemption prices if Carling failed to make any dividend payment. Elders' agreement was viewed with favor by the Canadian Bond Rating Services, which raised its rating of the preferred shares.

Despite the favorable reaction from the rating service, the plaintiffs' oppression claim succeeded before the Ontario Court of Appeal. The court acknowledged that "[a]s long as Elders remains willing and able to discharge its obligations under the support agreement, the preferred shareholders are probably in as good a position, or better, than that in which they would have been if there had been no amalgamation."193 Indeed, if Elders became unwilling to discharge its obligations, it seems that preferred shareholders would have a direct claim against the corporation. At a minimum, the preferred shareholders would be third-party beneficiaries of the support agreement. The court reasoned that, even with a willing and able Elders in the picture, "the persons who bought the preference shares, at least those who did so before the take-over, had not intended to invest in, or be dependent upon Elders. They had invested in a Canadian brewing company, not an Australian conglomerate." 194 No legitimate corporate purpose of Carling caused it to assume I.X.L.'s

192. Palmer, 67 O.R.2d at 164 . The court does not explain why no vote was necessary. Under the Ontario statute, an amalgamation agreement, once adopted by the directors of each amalgamating corporation, must be submitted to "the holders of the shares of each class or series entitled to vote thereon." OBCA, R.S.O. ch. 4 \& 175(4). Shares not otherwise entitled to vote have statutorily created voting rights if the amalgamation agreement contains a provision that triggers a statutory entitlement to vote as a class. Id. $\$ 175(3)$. The corporation's articles may exclude statutorily created voting rights for some types of provisions affecting the shares' treatment. See id. § 169(1). In any event, regardless of any provisions to the contrary in the corporation's articles, shares have the right to vote as a class if the amalgamation agreement adds to, removes, or changes the rights, privileges, restrictions, or conditions attached to shares; if it enhances the rights of a class having equal or superior rights; if it elevates to equality or superiority the rights of an inferior class; if it effects an exchange or creates a right to exchange shares of another class into the affected class; or if it adds, removes, or changes restrictions on the issue, transfer, or ownership of shares of the class. See id. $\S 169(1)$. The amalgamation agreement in Palmer may not have contained any provisions with such a triggering effect.

193. Palmer, 67 O.R.2d at 166.

194. Id. Unquestionably, U.S. courts have, on occasion, also treated an unconsented-to transformation in the nature of an enterprise as justifying relief for a minority investor. See Jones v. H.F. Ahmanson \& Co., 460 P.2d 464, 476-77 (Cal. 1969) (minority shareholder objected to controlling shareholders' transfer of their shares in a savings and loan association to a holding company, which subsequently went public). Commentators agree that Jones is an unusual case but differ on whether the case should be viewed as wrongly decided or as eccentric but influential. Compare FranK $\mathrm{H}$. EASTERbrooK \& Daniel R. Fischel, The Economic Structure of Corporate Laws 132 (1991) (asserting that the Jones court erred in failing to appreciate efficiency gains of permitting controlling shareholders to benefit exclusively from the consolidation of their business interests in a holding company) with William W. Bratton, The Economic Structure of the Post-Contractual Corporation, 87 Nw. UNIV. L. REV. 180, 201 (1992) (concluding that although invitation to compel gain sharing with minority 
acquisition debt. Carling's directors treated the preferred stockholders in a manner unfairly prejudicial to their interests, and unfairly disregarded their interests, by drastically changing the nature of their security interest in Carling and by "foist[ing] on them a claim against Elders without their consent or approval." 195 The court ordered Carling to make an offer to redeem the shares at the price applicable to a voluntary redemption.

In contrast, one strongly suspects that under Delaware law Elders would have been able to terminate the preferred shareholders' interests at a much lower price. In Rothschild International Corp. v. Liggett Group, Inc., ${ }^{196}$ a 1984 Delaware case, the plaintiff challenged a cash-out merger in the wake of a tender offer that eliminated a class of cumulative preferred stock at a price well below the redemption price applicable in the event of a liquidation. The court held that the merger did not constitute a liquidation and that the plaintiff's sole remedy was to dissent from the merger and seek the payment of the shares' "fair value" through an appraisal proceeding. ${ }^{197}$ "Fair value," the court noted, would entitle the plaintiffs "to an amount equal to their proportionate interests . . a as determined by 'all relevant factors." 198 The transaction in Rothschild differs from that in Carling O'Keefe because it triggered appraisal rights; under the applicable Canadian corporation statute, an amalgamation triggers appraisal rights only for shareholders entitled to vote on the resolution. ${ }^{199}$

represented by opinion in Jones has not been accepted by courts, case remains "good law" in its narrow sphere and constrains parties who plan transactions).

195. Palmer, 67 O.R.2d at 172. Palmer is not unique among Canadian cases in granting relief to preferred shareholders on the basis of an apparently remote prospect of injury to their interests. In the case Re Canadian Pacific Ltd., 73 O.R.2d 212 (Ont. H.C. 1990), the court's task was to determine whether a scheme of arrangement was fair and reasonable. See CBCA \& 192(3). The scheme amounted to a spin-off, which is a parent's distribution of shares in a wholly owned subsidiary to its own shareholders through a dividend. Canadian Pacific proposed to limit the spin-off distribution to its common shareholders, excluding its class of $4 \%$ nonparticipating preferreds. Although the court held, in a separate opinion, that the nonparticipating feature of the preferreds did not entitle them to receive the dividend, it also held that this same exclusion made the arrangement unfair and unreasonable. See Re Canadian Pacific Ltd., 72 O.R.2d 545, 569 (Ont. H.C. 1990). The court noted the absence of benefit to the corporation, the extraction of assets from the corporation, and the possibility that the corporation might at some future point be liquidated (with perhaps fewer assets to distribute to the preferreds). See Canadian Pacific, 73 O.R.2d at 228-32.

196. 474 A.2d 133 (Del. 1984).

197. Id. at 137.

198. Id.

199. See OBCA, R.S.O. $§ 184(1)$ (c). Is the Carling transaction itself feasible under the Delaware statute without triggering appraisal rights? The Delaware merger statute limits shareholder voting rights to "the outstanding stock of the corporation entitled to vote thereon." See DEL. CoDE ANN. tit. 8, § 251(c) (1974). Shareholders have a statutorily mandated right to vote as a class on any certificate amendment

if the amendment would increase or decrease the aggregate number of authorized shares of such class, increase or decrease the par value of the shares of such class, or alter or change the powers, preferences or special rights of the shares of such class so as to affect them adversely.

Id. $\S 242(\mathrm{~b})(2)$. Suppose the merger transaction-as may have been true for the Carling transaction-required no amendment to the corporation's certificate. In that event, no vote of the surviving corporations shareholders will be necessary if, under the merger agreement, the corporation will not issue common shares exceeding more than $20 \%$ of its shares outstanding immediately prior to the merger. 
The emphasis in Rothschild, as in Metropolitan Life, is on the primacy of express contract, even though the securities in Rothschild represented equity rather than debt interests. "Preferential rights," observed the Rothschild court, "are contractual in nature and therefore are governed by the express provisions of a company's certificate of incorporation. Stock preferences must also be clearly expressed and will not be presumed." ${ }^{200}$ In Carling O'Keefe, in contrast, the court focused on the expectations of the preferred shareholders that remained undefined by contract (for example, that Carling would remain a Canadian company), ultimately expanding the range of transactions that triggered a premium liquidation payout.

Indeed, it seems likely that the outcome in Metropolitan Life would differ under oppression analysis. A variety of creditors have successfully pursued oppression actions in response to actions by corporate debtors to which they objected. ${ }^{201}$ Like the shareholders in Carling O'Keefe, the Metropolitan Life plaintiffs invested in light of significant expectations for RJR Nabisco that were neither defined nor articulated in express contract terms. ${ }^{202}$ The highly leveraged company that emerged from the LBO was, financially at least, drastically metamorphosed from the company in which they had invested initially. To alleviate a perceived "oppression risk" on the litigation front, directors embarking on an LBO could voluntarily offer redemption to holders of debt securities. To fund the redemption, the directors might either borrow more in the LBO (if the funds are available) or structure the transaction to pay a proportionately lower premium to the corporation's shareholders. In the latter scenario, the oppression constraint on directors leads to less favorable treatment of its pre-LBO shareholders, other things being equal; in the former scenario, post LBO-shareholders (and other corporate constituents, for that matter) have

\section{Id. \& 251(f).}

200. $474 \mathrm{~A} .2 \mathrm{~d}$ at 136 . Indeed, this view of preferred stock may well cut off the allegation that, by approving a merger transaction structured to resemble the Carling transaction, the corporation's directors breached a fiduciary obligation owed to the preferred stockholders. One might argue that the directors, acting at the bidding of the sole common stockholder, were conflicted in approving a merger detrimental to the preferreds' interests. See supra note 121 . But the interests at issue are simply preferential rights, "contractual in nature and therefore ... governed by the express provisions of a company's certificate of incorporation." Rothschild, 474 A.2d at 136. The terms of the merger, it is assumed, did not contravene any of the express provisions in the certificate. Nor did the Carling transaction entail a distribution of assets; assets simply became encumbered. Should the encumbrance be treated as waste? It furthers the interest of one cohort of Carling stockholders, specifically, the interest of its sole common shareholder.

201. See, e.g., R. v. Sands Motor Hotel, Ltd., [1985] 1 W.W.R. 59 (Sask. Q.B.) (distributions of corporate assets successfully contested by the Crown because they left corporate taxpayer with no funds available to pay taxes; the Crown pursuing collection of a revenue debt due Canada, is a proper creditor complainant under oppression statute); Canadian Commercial Bank v. Prudential Steel Ltd., 49 Alta. L.R.2d 58 (Q.B. 1986) (unsuccessful attempt by bank creditor to void sale of inventory as fraudulent conveyance; court limits oppression action to remedies against corporation in which complainant holds its security).

202. See also Brian R. Cheffins, An Economic Analysis of the Oppression Remedy: Working Towards a More Coherent Picture of Corporate Law, 40 U. TORONTO L.J. 775, 807 (1990) (noting Canadian courts' relative lack of inhibition, in oppression actions, in revisiting matters addressed by express terms). 
interests in a highly leveraged company that has, most likely, refunded old debt with (more expensive) new debt.

\section{$\mathrm{V}$ \\ CONCLUSION}

What explains the differences between Canadian and U.S. norms explored in this article? Canadian commentators stress the relative conservatism of Canadian judges and the lingering influence of English law in explaining why Canadian courts have not followed the lead of their counterparts to the south in imposing a fiduciary obligation on majority shareholders. ${ }^{203}$ Characteristics of judges, though, do not explain the distinctive legislative contribution to corporate law made by the Canadian oppression statutes.

The contrasts explored in this article are only elements in larger interrelated systems, creatures in a larger ecosystem of corporate law, regulation, and practice. $^{204}$ The Canadian system, in many respects, reflects a dominant value of egalitarianism. The regulation of corporate takeovers in Ontario and Quebec, for example, mandates equal treatment of target shareholders to a much greater degree than does the counterpart regulation in the United States. Indeed, under the Ontario Securities Act, subject to a few exceptions, any transaction in which a person acquires twenty percent or more of a class of shares is defined to be a takeover bid, which must be made at the same price to all holders in the same class. ${ }^{205}$ By legislation, Ontario defines corporate control to be an asset of the corporation. The Canadian oppression statutes, similarly, reflect an egalitarian norm that equates the protectible interests of shareholders with those of nonshareholder constituents. To pursue the ecological metaphor a bit further, these statutes structure the Canadian ecosystem with less differentiation among species than do the counterpart norms that shape the U.S. ecosystem. The Canadian oppression statutes minimize the special status of equity investment. By doing so, they make it difficult for a court-such as that in KeepRite - to attach explicit fiduciary constraints to any particular relationship created by the corporate form of organization.

On the specific issues examined in this article, the Canadian resolution seems to disfavor clearly drawn demarcations that differentiate among interests created by the varied relationships creditors, shareholders, and other parties have to a corporation. Moreover, the Canadian resolution seems to create weaker, rather than stronger, incentives for ex ante definitions of entitlements. Looking north from the United States, one might recall the contrasting images from Professor Carol Rose's classic article, Crystals and Mud in Property Law. ${ }^{206}$ Crystals, writes Professor Rose, are rules of law that clearly, specifically, and narrowly

203. See, e.g., MacIntosh, supra note 45, at 136.

204. See Hill, supra note 51, at 103 (introducing metaphor of corporate law as an ecosystem).

205. A key exemption is for "private purchases," defined as purchases from five or fewer shareholders at a price less than $115 \%$ of market price. See OSA, 11 R.S.O. ch. S-5 $\$ \S 93(1)$ (c)(i), (iii).

206. Carol M. Rose, Crystals and Mud in Property Law, 40 STAN. L. ReV. 577 (1988). 
define entitlements in advance of disputes among concerned parties. "Mud rules," in contrast, are fuzzy and ambiguous rules of decision that create opportunities for judicial second-guessing based on ex post examinations of numerous factual circumstances. For example, the early common law mortgage was as crystalline as a pawn shop transaction; courts of equity, by judicially enlarging the debtor's time to pay before final foreclosure, created a fact-specific "mud rule" of excuse. ${ }^{207}$ Crystal rules seem to typify the preconditions needed to encourage one-shot dealings among strangers, who would wish, within the limits of language, to define and bound all relevant entitlements. In contrast, courts adopting "mud rules" in effect reinstate[] the kind of weighing, balancing and reconsidering that the parties might have undertaken if they had been in some longer term relationship with each other." 208 The Canadian oppression statutes are the quintessential "mud rules" in corporate law; much more than fiduciary concepts, they frustrate attempts to define entitlements in advance.

Certain features of the Canadian corporate ecosystem might explain the egalitarian treatment mandated for change of control transactions. Highly concentrated corporate ownership makes Canadian capital markets small places, dominated by a relatively small number of players. It might be difficult to attract public equity investment into a market visibly dominated by corporate insiders and other large players, in the absence of a mandatory assurance of equal treatment in connection with sales of control. ${ }^{209}$ Sales of control are, among their other traits, transactions that combine visible opportunities for the selling shareholders to profit with less visible opportunities for the purchaser to exploit the corporation's assets and the nonselling shareholders. ${ }^{210}$

Moreover, the concentrated nature of corporate ownership in Canada might help explain the popularity of the "mud rule" solutions encouraged by oppression statutes. In a concentrated economy, one with a small number of major players, each player-large shareholder, bank lender, institutional holder of debt securities-may have more than one relationship with other players. When disputes occur in a world typified by multidimensional relationships, inhabitants may prefer accommodation and readjustment to an invariant insistence on openand-shut resolution. The generalized entitlement to fair treatment created by oppression statutes, in short, may mirror Canadian economic practices or Canadians' normative assumptions about what economic practices should be. The drawback of this explanation is that these ownership patterns preceded by

207. Id. at 583-84.

208. Id. at 608-09.

209. It is also arguable, as one Canadian commentator forcefully maintains, to characterize this equality requirement as reflecting "traditional fiduciary obligations, owed by directors to their corporations or by majority to minority shareholders," or at least as reflecting an extension of fiduciary norms by analogy. See Philip Anisman, The Commission as Protector of Minority Shareholders, in LAw SOCIETY OF UPPER CANADA, SPECIAL LECTURES 1989: SECURITIES LAW IN THE MODERN FINANCIAL MARKETPLACE 451, 463 (1990).

210. See Jesse H. Choper et al., Cases and Materials on Corporations $1055-67$ (3d ed. 1989). 
many years the mid-1970s' enactment of oppression legislation. It may be, however, that the oppression legislation, which enables small shareholders to challenge conduct that historically was relatively invulnerable, is explicable as part of a program to make public investment in Canadian securities markets more widely attractive. ${ }^{211}$

The Canadian ecosystem also features a prominent role for organs of government-legislative and administrative-in defining and enforcing rules for private parties' conduct. Less turns on private litigation than in the United States because more is controlled at the outset by mandatory legislative rules or administrative supervision. Why this might be is well beyond the scope of this article. One recalls, though, that the Canadian constitution has long been expressly directed toward enabling its citizens to achieve "Peace, Order and Good Government," but not (at least expressly) "Life, Liberty and the Pursuit of Happiness."

In any event, by creating such strong incentives for ex ante definitions of entitlements, the U.S. ecosystem has nurtured conduct toward creditors perceived in many quarters to be opportunistic. ${ }^{212}$ Sharply drawn demarcations among types of interests may yield greater predictability and intellectual neatness than do more loosely structured constructs, but intellectual tidiness does not in itself make outcomes palatable.

211. A thoughtful critique of prior corporate law in Canada and a detailed set of reform proposals preceded enactment of the CBCA in 1975. See generally DICKERSON ET AL., supra note 24. The report explicitly endorsed Professor Ballantine's view that corporation laws "provide the legal frame and financial structure of the intricate corporate device by which business can be carried on and in which the combined energies and the capital of the managers and of many investors may work together." Id. at 3 (quoting H.W. Ballantine, Ballantine ON CoRPORATIONS 41-42 (1946)). It is evident that individuals have many alternative uses for household surplus, including additional consumption. Moreover, the attractiveness of selecting particular investment choices is affected by the risk of exploitative behavior by persons who actively manage assets or, less directly, persons who control the active managers. That risk is not entirely mitigated by the availability of pooled investment vehicles, such as pension funds and mutual funds; such funds may be large investors, but they do not often possess or exercise control. Nor is it likely that all, or even most, prospective investors can fully diversify their investment portfolio against the particular risk of exploitative behavior. How would an "outsider" considering investing in a subsidiary corporation be able to assess the parent's future propensity to exploit minority investors in subsidiary corporations? Past practice may be indicative, but also may not be repeated in the future. The optimal degree and style of protection against exploitative behavior are rarely self-evident.

212. See Brudney, supra note 186. 